\title{
Okul Yönetimine Katılım: Rehber Öğretmenler Üzerine Bir Araştırma
}

\section{Participation in School Management: A Research on School Counselor}

Ertuğ Can ${ }^{\mathrm{a}, *}$, Urania Nikolayidis ${ }^{\mathrm{b}}$

${ }^{a}$ Doç. Dr., Kırklareli Üniversitesi, Fen Edebiyat Fakültesi, Eğitim Bilimleri Bölümü, 39000, Kırklareli/Türkiye. ORCID: 0000-0002-0885-9042

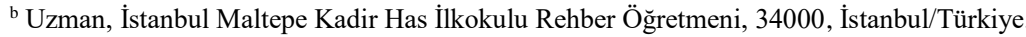
ORCID: 0000-0003-4287-5211

\section{MAKALE BILGISİ}

\section{Makale Geçmişi:}

Bașvuru tarihi: 01 Temmuz 2020

Düzeltme tarihi: 27 Eylül 2020

Kabul tarihi: 04 Ekim 2020

\section{Anahtar Kelimeler:}

Okul yönetimi

Okul yönetimine katılım

Rehber öğretmen

Yönetime katılım

\section{A R T ICLE INFO}

\section{Article history:}

Received 01 July 2020

Received in revised form 27 September 2020

Accepted 04 October 2020

\section{Keywords:}

School management

Participation in school management

School counselor

Participation in management
ÖZ

$\mathrm{Bu}$ araştırmanın amacı, resmî kurumlarda görevli rehber öğretmenlerin okul yönetimine katılım durumlarını belirlemektir. Araştırmada, nitel araştırma yöntemi kapsamında fenomenoloji deseni kullanılmıştır. Araştırmanın çalışma grubu, 2019-2020 öğretim yılında İstanbul'da görevli 31 rehber öğretmenden oluşmaktadır. Araştırmanın verileri 6 açık uçlu soru ile bireysel yüz yüze görüşmeler yapılarak toplanmış ve içerik analizi ile değerlendirilmiştir. Araştırma sonuçlarına göre, rehber öğretmenlerin okul yönetimine katılımları yeterli görülmemektedir. Rehber öğretmenler, genellikle resmî toplantılar yoluyla okul yönetimine katılmaktadır. Rehber öğretmenlere göre, okul yönetimine katılım sorunların çözümü, iş birliği ve kararlara katılma bakımından gerekli ve önemlidir. Ancak bazı nedenlerle, rehber öğretmenler okul yönetimine etkili olarak katılamamaktadır. Rehber öğretmenlerin okul yönetimine etkili katılımını sağlamak için, yasal düzenlemeler yapılması, rehberlik hizmetlerinin düzenlenmesi, çalışma koşullarının iyileştirilmesi, yönetici ve öğretmenlerin eğitilmeleri faydalı olabilir.

\section{A B S T R A C T}

The purpose of this research is to determine the participation status of the school counselors working in official institutions to school management. In the research, phenomenology design was used within the scope of qualitative research method. The study group of the research consists of 31 school counselors working in Istanbul in the 2019-2020 academic year. The data of the research were collected by making individual face-to-face interviews with 6 open-ended questions and evaluated with content analysis. According to the results of the research, the participations of school counselors in school administration is not considered sufficient. School counselors usually participate in school management through formal meetings. According to the school counselors, participation in school management is necessary and important in terms of solving problems, cooperation and participation in decisions. However, for some reasons, school counselors cannot participate effectively in school management. In order to ensure effective participation of school counselors in school management, it may be beneficial to make legal arrangements, arrange of guidance services, improve of working conditions, training of managers and teachers.

\section{Giriș}

Açık sistem özelliğine sahip olan okullar, eğitim biriminin en alt kademesinde ve toplumun içinde yer alan en önemli kurumlardan biridir. Okulun etkililiğinde en önemli öğelerden biri okulun yönetimidir. Taymaz'a (1989) göre, eğitim yönetiminin sınırlı bir alana uygulanması olan okul yönetimi, okulun bir karar alma birimidir. Okulların yönetiminde, etkililiğinde ve başarısında, etkili okul yönetiminin ve okul yönetimini etkileyen öğelerin büyük rolü bulunmaktadır. Bursalığlu'na (2000) göre, bir okulun yönetiminde rol oynayan en önemli öğeler arasında yöneticiler, öğretmenler, öğrenciler, memurlar ve diğer personel yer almaktadır. Ayrıca, ana-baba, çevredeki baskı grupları ve liderler, yönetim yapısı, iş piyasası ve merkez örgütü de okul yönetimini etkilemektedir.

\footnotetext{
* Sorumlu yazar/Corresponding author.

e-posta: ertugcan@gmail.com
} 
Okul yöneticilerinin okulun etkililiği için başta öğretmenler olmak üzere, okulda alınacak kararlardan etkilenecek kişileri, birer karar organı olarak görüp kabul etmesi ve karar sürecine katması gerekir. Çünkü, Bursalıŏglu'na (2000) göre, yönetim süreçlerinin merkezini oluşturan karar, örgütlerin yaşamasında büyük öneme sahiptir. Bu yüzden, kararların uygulanabilirliğini sağlamak ve okulu amaçlarına uygun olarak yaşatabilmek için kararlardan etkilenecek bireylerin karara katılımını sağlamak gerekmektedir. Okulu amaçlarına uygun yaşatmanın en önemli yollarından biri ise okuldaki insan ve madde kaynaklarını amaçlara göre harekete geçirmek, eşgüdümlemek ve öğretmenlerin okul yönetimine katılımlarını sağlamaktır. Okulda alınan kararların öğrenciler, öğretmenler, çalışan personel, veliler ve diğer kurumlar ile üst birimleri de etkilediği dikkate alındığında, öğretmenlerin okul yönetimine katılımlarının gerekli ve önemli bir konu olduğu söylenebilir.

Mevcut okul sistemlerindeki insan ilişkilerinin ve etkinliklerinin karmaşıklığı, nitelikli bir eğitim hizmetinin sunulmasında bir avantaj olarak öğretmenlerin okul yönetimine katılımı ihtiyacını artırmıştır (Sharma, \& Kumari, 2017). Okul yönetimine katılma; "öğretmenlerin, öğrencilerin ve velilerin okulda kararların alınma sürecine katılmasını gerektirir" (Karakütük, 2001, s. 23). Okullarda, okulun tüm öğelerinin (öğretmen, öğrenci, aile) okul yönetiminde kendilerini ilgilendiren kararlara katılımlarının sağlanması demokratik okulun koşuludur (Karaman-Kepenekçi, 2003). "Okul yöneticisi, yönetimde bilimsel ilkeleri uygularken kararlardan etkilenen unsurları karara katması gerekir" (Şişman ve Turan, 2003, s. 314). "Karardan etkilenecek kişilerin karara katılması görüşü, 1930'lardan itibaren eğitim yönetimi kuramcıları tarafindan da savunulmuştur. Bu savunmanın temelinde, katılmalı kararların daha geçerli ve uygulanabilirlik olasılığının daha yüksek olacağı inancı yatmaktadır" (Alıç, 1996, s. 177). Özdemir (1996), okul ile ilgili kararların, okul ile ilgili en yakın insanlar tarafından alınmasını, yani okula dayalı yönetimin önemli olduğunu belirtmektedir. Okul yönetimine katılım, okulda alınan kararlarda söz sahibi olma, bu konuda sorumluluk alma, okul yönetimine etkide bulunma olarak tanımlanabilir. Burada, öğretmenlerin okul yönetimine katılımlarından aslında okul yönetim süreçlerine katılımını anlayabiliriz. Yani, etkili bir okul yönetiminin temel unsurları olan, planlama, örgütleme, personel alma, yöneltme, eşgüdümleme, bilgi verme, bütçeleme, iletişim ve denetleme (Aydın, 1994; Başaran, 1996), olarak belirtilen yönetim süreçlerine öğretmenlerin katılımı kastedilmektedir. Mondal'a (2016) göre, öğretmenler okul yönetimine planlama, organizasyon, iletişim, kontrol ve değerlendirme süreçlerinde katılım sağlamalıdır. Güçlüol da (1985), eğitim örgütlerinde karara katılmanın gerekli ve önemli bir konu olduğunu belirtmektedir.

Öğretmenler, bu yönetim süreçlerine ne derece etkili katılım sağlayabilirlerse, okul yönetimine katılımlarının da etkili olabileceği söylenebilir. Kartal'ın (2008) belirttiği gibi, okul yönetiminde kararların sonuçlarından etkilenen, karar konusunda uzmanlığı olan ve kararı uygulama sorumluluğu olan herkesin karar sürecine katılması hem demokratik okulun hem de çağdaş yönetimin gereğidir. Hoy ve Miskel'e (2012) göre, okullardaki karar verme sürecine katılım, öğretmenlerin bireysel ve meslekî doyumlarını olumlu yönde etkilemekte, öğretmenler de kendilerini karar verme sürecine dahil eden müdürleri tercih etmektedir.
Öğretmenlerin okul yönetimine katılımı konusunda pek çok araştırma bulgusuna rastlanmaktadır. Balyer, Özcan ve Yıldız (2017), öğretmenlerin okuldaki kararlara katılımlarının öğretmenlerin güçlendirilmesine ve meslekî gelişimlerinin sağlanmasına önemli katkılar sağlayacağını belirtmektedir. Mosoge, \& Van Der Westhuizen (1998), okul temelli yönetim anlayışında öğretmenlerin önemli rol ve sorumlulukları bulunduğunu ve öğretmenlerin yönetime katılımlarının gerekli olduğunu belirtmektedir. Göksoy da (2014a), öğretmenlerin okul yönetiminde karar alma sürecine katılım düzeylerinin artırılması gerektiğini belirtmektedir. Çünkü, Adegoke'a (2010) göre, öğretmenlerin okuldaki karar alma sürecine katılımları ile iş üretkenliği arasında anlamlı bir ilişki bulunmaktadır. Özden'e (1996) göre, katılmalı yönetim bütün örgütlerde demokratikleşmenin bir gereği olarak ön plana çıkan bir yönetim şeklidir. Öğretmenlerin okul yönetimine katılımlarının bir anlam ifade edebilmesi için, görüş belirtmelerinin dışında, problemlerin çözüm aşamalarında da yer almaları ve alınan kararlara katılım sağlamaları gerekmektedir. Başaran'ın (1986) belirttiği gibi, örgütlerde yönetici-yönetilen ilişkilerinin gelişmesi, sağlıklı bir çalışma ortamı yaratılması, yönetsel kararlarda objektifliğin sağlanması ve alınan kararların tam olarak uygulanabilmesi için yöneticilerin personelin kararlara katılması konusunda çaba harcaması gerekmektedir. Ancak, Celep'e (1990) göre, Türk Eğitim Sisteminin mevcut yapıs1 içerisinde, okul yöneticilerinin okul politikasını belirleme, çevre koşullarına göre yeni amaçlar saptama ve bu doğrultuda kararlar alması söz konusu olmadığından, daha doğrusu okul yönetiminin karar alma yetkisi bulunmadığından, karara katılma da gerçekleşememektedir. Günümüzde de bu sorunun varlığını devam ettirdiği söylenebilir. $\mathrm{Bu}$ durum, aynı zamanda eğitim yönetiminin merkezîleşmesinin ve izlenen eğitim politikalarının bir sonucu olarak görülebilir. Balcı'nın (2001) da belirttiği gibi, okulların fonksiyonlarını yerine getirmeleri öğretmenler aracılığıyla gerçekleştiği için, öğretmenlerin okula yönelik etkilerini sınıfla ve görev alanları ile sınırlı tutmamak gerekir. Yani, öğretmenlerin öğretim görevleri dışında, okuldaki yönetsel süreçlere katılımlarını sağlamak gerekir.

Öğretmenlerin okullardaki karar süreçlerine etkili katılım sağlamaları ve böylece okulu benimseyerek, yaptıkları işten doyum elde etmelerine yardımcı olacak düzenlemelere ihtiyaç bulunmaktadır (Özden, 1996). Çünkü, eğitim ile ilgili karar süreçlerine katılım, demokrasinin gelişmesi açısından son derece önemlidir (Şişman, 2006). Demokratik anlayışın yerleştiği okullarda, yönetsel ve politik kararlar geniş katılımlı bir anlayışla belirlenir. Bu yüzden okullardaki her türlü kurul, komisyon ve toplantılar, tüm çalışanların ve paydaşların geniş bir katılımı ile gerçekleştirilmelidir (Apple, \& Beane, 2011). Okuldaki karar alma sürecine öğretmenlerin katılım sağlaması, iş birliği, eşgüdüm, bilgi alışverişi ile öğrenci başarısını olumlu yönde etkilemektedir (Goddard, Goddard, \& Tschannen-Moran, 2007; Westheimer, 2008).

Görüldüğü gibi, öğretmenlerin katılım sağladığı okul yönetimlerinde öğrenci başarısında artış, okulun etkili yönetimi gibi olumlu sonuçlar ortaya çıkabilmektedir. Okul yöneticisi, öğretmenler, personel ve veliler arasındaki ilişkiler de olumlu etkilenebilmektedir. Njoroge ve Kathuri'ye (2017) göre, katılımc1 okul yönetimi okulun etkililiğinin ve verimliliğinin iyileştirilmesinde uzun süredir temel bir bileşen olarak kabul edilmektedir. Lalruatsanga'ya (2016) göre, öğretmenlerin okul yönetimine katılımları 
gerekmektedir. Çünkü, öğretmenlerin okul yönetimine etkili katılım sağlamaları, okul içi disiplini de olumlu etkileyecektir. Öğretmenlere okul yönetimi faaliyetlerinde sorumluluk verilirse, öğretmenlerin iyi bir performans göstereceği belirtilmektedir. Hallak'a (1995) göre ise öğretmenlerin yönetime katılımını esas alan okul tabanlı yönetim anlayışında, eğitimin kalitesi için daha fazla iş birliği, eğitim planlaması ve uygulamasında ortaklığın güçlendirilmesi gerekir. Böylece, okul yönetiminin daha demokratik olacağı, sorumlulukların daha adil paylaşılacağı, okulda kalite ve verimliliğin artacağı belirtilmektedir. Şüphesiz, öğretmenlerin okul yönetimine etkili katılımı, eğitim sisteminde karar verme gücünün dağılımında ve sağlıklı kararların alınmasında en önemli değişikliklerden biri olarak vurgulanabilir.

Öğretmenlerin okul yönetimine katılım yöntemleri arasında okul yöneticilerinin öğretmenlere uzmanlık alanlarına göre yetki devri sağlaması gösterilebilir. Elma'nın (2000) belirttiği gibi, yetki devri sihirli bir değnek olmamakla birlikte, çalışanlar açısından önemli bir firsat olup, onları güdüler, işe ve örgüte bağlılıklarını artırır, karar verme özerkliği sağlar, kendilerini yetiştirme ve geliştirmeye katkı sağlar. Yetki devri ile öğretmenlerin okul yönetimine katılımlarının sağlanması, okulun ve çalışanların başarısını olumlu etkileyecektir. UNESCO (2018), öğretmenlerin rollerinin sınıf sorumluluklarının dişına genişletilmesi, ulusal düzeydeki tartışmalara ve eğitim politikasına yönelik kararlara katılımının teşvik edilmesi gerektiğini, aksi takdirde öğretmenlerin karar alma süreçlerinden dışlanmalarının kararların uygulanma olasılığını düşüreceğini belirtmektedir. Conley (1991), öğretmenlerin en fazla sınıf düzeyinde kararlara katılabildiklerini ancak, okul düzeyindeki yönetimsel kararlara yeterli katılım sağlayamadıklarını belirtmektedir. Chopra'ya (2020) göre, eleştirel düşünmeyi kolaylaştıran, karar alma süreçlerine ve uygulamalarına katılımlarını sağlamak için hem öğretmenleri hem de öğrencileri içeren demokratik ve kapsayıcı alanlara erişimin artırılması gerekmektedir. Ancak, alan yazında yer alan bazı araştırma bulguları (Aksay ve Ural, 2008; Aldemir, 1996; Babaoğlan ve Yılmaz, 2012; Balyer, Özcan ve Yıldı, 2017; Bilge, 2008; Can, Gündüz ve Işık-Can, 2013; Can ve Bayramoğlu, 2016; Can ve Serençelik, 2017; Can ve Ozan, 2020; Chopra, 2020; Conley, 1991; Güçlü, Özer, Kurt ve Koşar, 2015; Gürkan, 2006; Karagöz, 2009; Karakütük, 2001; Karaman-Kepenekçi, 2003; Öner, 2007; Üzüm ve Kurt, 2019; Şişman ve Turan, 2003; Sharma, \& Kumari, 2017; UNESCO, 2018; Taiwo, \& Ogunlade, 2020), öğretmenlerin okul yönetimine etkili ve yeterli katılım sağlayamadıklarını, bu konuda bazı engellerle karşılaştıklarını, okul toplantılarının etkili olmadığını, yönetici ve öğretmenlerin yetiştirilmesi başta olmak üzere, yasal ve pedagojik çabalara ihtiyaç olduğunu ortaya koymaktadir.

Okulun başarısı ve alınan kararların etkililiğinde rehber öğretmenlerin de okul yönetimine katılımının büyük etkisi olduğu söylenebilir. Çünkü, okulun etkililiğinde büyük önem taşıyan, okul rehberlik faaliyetlerini yürüten rehber öğretmenlerin görev ve sorumlulukları kısaca incelendiğinde (MEB, 2020), gelişimsel ve önleyici hizmetler (sınıf içi etkinlikler, bireyi tanıma çalışmaları, bilgi verme çalışmaları, yöneltme ve izleme çalışmaları), iyileştirici hizmetler (sosyal, duygusal, akademik, kariyer gelişimi, psikolojik danışma, aile, ögrenci, yönetici, öğretmen ve çevreye yönelik psiko- sosyal destek hizmetleri) ve destek hizmetleri (aile, öğrenci, yönetici, öğretmen ve çevreye yönelik müşavirlik) kapsamında oldukça kapsamlı ve önemli fonksiyonları olduğu, okulun tüm girdileri ve çevresi ile yakın ilişki ve iş birliği içerisinde olması gerektiği anlaşılmaktadır. Bu durum, rehber öğretmenlerin okul yönetim süreçleri ve kararlara katılımının gerekli ve önemli olduğunu ortaya koymaktadır. Camadan ve Sezgin'e (2012) göre, rehberlik birimi ile okul yöneticilerinin iş birliği yapması, okul yöneticilerinin rehberlik birimine yönelik olumlu algıları ve rehberlik çalışmalarına katılımı, eğitim kurumlarının kalitesine olumlu katkı sağlamaktadır. Ancak, burada kastedilen katılım ve iş birliğine aynı zamanda rehber öğretmenlerin okul yönetimine ve okulda alınan kararlara katılımını da eklemek faydalı olacaktır. Çünkü, rehberlik hizmetlerinin başarılı olmasında veli, öğretmen, öğrenci, yönetici, sivil toplum örgütleri, kamu kurumları ve diğer ilgililerin iş birliği ve katılımının büyük önemi olduğuna yönelik araştırma bulguları (Can, 2011; Can, Nikolayidis, \& Işı-Can, 2018; Erkan, 2001; Kuzgun, 2009; Şahin, 2010) bulunmaktadır.

Rehberlik hizmetleri yönetmeliğine (MEB, 2017) göre, rehber öğretmenler tüm öğretim kademelerinde öğrenci, öğretmen, yönetici ve çevreye yönelik eğitsel, meslekî, kişisel/sosyal alanlarda bireysel ve grupla rehberlik, aile rehberliği, yönlendirme ve danışmanlık faaliyetleri yapma, yapılan çalışmaların sonuçlarını kurum ve kuruluşlarla iş birliği içinde paylaşma amacıyla farklı görev ve sorumlulukları yerine getirmektedir. Yönetmeliğe (MEB, 2017; MEB, 2020) göre, eğitim kurumlarındaki rehberlik hizmetlerinin yürütülmesinde rehber öğretmenlerin rehberlik hizmetleri yürütme komisyonunda önemli görev, rol ve sorumlulukları bulunmaktadır. Rehberlik hizmetleri yürütme komisyonunun görevleri (MEB, 2017; MEB, 2020) incelendiğinde, eğitim ortamında; öğrenciler, aileler, idareciler ve öğretmenler arasında etkili iletişim kurulabilmesi için yapılacak çalışmaların belirlenmesi, ögrencilerin sosyal, duygusal, akademik ve kariyer gelişimleri ile ilgili yapılacak çalışmalar için görüş bildirilmesine yönelik çalışmalar, rehber öğretmenlere kararlara katılımda etkin bir sorumluluk yüklemektedir. Okul rehberlik hizmetlerinin etkililiği bakımından, okul yöneticileri ve rehber öğretmenlerin karş1lıklı olarak önemli rol ve fonksiyonları olduğu görülmektedir. Ancak, Meşeci, Özcan, Bozdemir ve diğerlerine (2007) göre, rehberlik hizmetlerinin fonksiyonu, okul yönetimleri ve öğretmenlerce yeterli düzeyde kabul görmediğinde, okul psikolojik danışma ve rehberlik servisi ile bu serviste görevli olanlar yeterli düzeyde hizmet veremezler. Bu yüzden, rehber öğretmenlerin okul yönetimine etkili katılımı için rehberlik hizmetlerinin okul yönetimi ve ögretmenler tarafından benimsenmesinin de büyük etkisi bulunmaktadır.

\section{Araştırmanın Önemi}

Ulusal düzeyde, rehber öğretmenlerin okul yönetimine katılım durumlarına ilişkin bir araştırmaya rastlanmamış olup, araştırma bu alanda yapılan ilk araştırmalardan biri olması bakımından büyük önem taşımaktadır. Rehber öğretmenlerin okuldaki rol ve sorumluluğu, diğer branş öğretmenlerinde olduğu gibi, belirli bir sınıftaki öğrenciler ve veliler ile sınırlı olmayıp, okuldaki tüm öğrenciler, veliler, öğretmenler, yöneticiler, çalışanlar ve çevre ile yakından ilişkilidir. $\mathrm{Bu}$ rol, görev ve sorumluk alanının genişliği, rehber öğretmenlerin okul yönetimi ile doğrudan ve daha 
yakın bir iletişim ve iş birliği içinde çalışmalarını gerektirmektedir. $\mathrm{Bu}$ durum, rehber öğretmenlerin okullarda alınan kararlarda okul yönetimine katılımlarının, destek olmalarının gerekli ve araştırılması gereken önemli bir konu olduğunu göstermektedir.

Rehber öğretmenlerin okul yönetimine ve okulda alınan kararlara etkili katılım sağlamalarının okul rehberlik hizmetlerinin etkililiği ile okulun başarısını artıracağ söylenebilir. $\mathrm{Bu}$ yüzden, rehber öğretmenlerin toplantılar başta olmak üzere, okul yönetimine nasıl ve ne düzeyde katılım sağladıklarının belirlenmesi, eğitim-öğretim faaliyetlerinin etkililiğine olumlu katkı sağlaması bakımından büyük önem taşımaktadır. Ayrıca, araştırma sonuçlarının rehber öğretmenlerin okul yönetimine etkili katılımlarının sağlanmasında okul yöneticilerine, alan uzmanlarına, öğretmenlere, politika yapıcılarına, konu ile ilgilenenlere katkı sağlayacağı değerlendirilmektedir.

\section{Araştırmanın Amacı}

$\mathrm{Bu}$ araştırmanın amacı, resmî kurumlarda görevli rehber öğretmenlerin okul yönetimine katılım durumlarını belirlemektir.

Araştırmanın problem cümlesi "Rehber öğretmenlerin okul yönetimine katılım durumları nasıldır? şeklinde ifade edilmiştir. Bu kapsamda aşağıdaki sorulara yanıt aranmıştır: Resmî kurumlarda görevli rehber öğretmenlerin;

1.Okul yönetimine katılım konusundaki görüşleri nelerdir?

2.Okul yönetimine katılımları nasıl gerçekleşmektedir?

3.Okul yönetimine katılım alanları nelerdir?

4.Okul yönetimine katılımlarının etkileri nelerdir?

5.Okul yönetimine katılımlarını etkileyen değişkenler nelerdir?

6.Okul yönetimine etkili katılımları için neler yapılabilir?

\section{Yöntem}

$\mathrm{Bu}$ bölümde araştırmanın modeli, çalışma grubu, veri toplama araçları, verilerin toplanması, verilerin analizi ile araştırmanın inandırıcılık ve tutarlılığına ilişkin bilgiler yer almaktadır.

\subsection{Araştırma Modeli}

Araştırmada daha derinlemesine ve zengin veriler elde etmek, katılımcıların alana ilişsin tecrübelerini öğrenebilmek amacıyla nitel araştırma yöntemi tercih edilmiştir. Glesne'nin (2013) belirttiği gibi, nitel araştırma, kelimeler ve gözlemler gibi ölçülmesi zor olan nitelikler üzerine odaklanan ve niteliklerin yorumlanmasına ve çözümlenmesine dayanan bir araştırma türüdür. Strauss ve Corbin'e (1988; akt. Ekiz, 2013) göre, nitel araştırmalarda, araştırma yapılan veya yapılması planlanan kişilerin yaşamış oldukları tecrübeler ve kişisel görüşlerine göre oluşan anlamlar, sistemli bir şekilde incelenebildiği için araştırmacılar tarafından tercih edilmektedir. Nitel araştırmalarda genellikle gözlem, görüşme ve doküman analizi gibi veri toplama tekniklerinden yararlanılmaktadır. Nitel araştırmalarda, algılar ve olayların doğal ortamlarda daha gerçekçi ve bütüncül bir yaklaşımla belirlenmesi hedeflenmektedir (Yıldırım ve Şimşek, 2006). Nitel araştırmalarda betimlemeler genellikle sayılar yerine cümlelerle yapılır. Böylece, incelenen olgu ile ilgili kapsamlı ve zengin veri sağlanmış olur. Nitel araştırmalarda, veri toplama teknikleri olarak genellikle gözlem ve görüşme kullanılmaktadır (Gliner, Morgan, \& Leech, 2015).

Araştırma, nitel araştırma türlerinden fenomenoloji deseninde gerçekleştirilmiştir. Sönmez ve Alacapınar'a (2013) göre bu desen, olayları, durumları, deneyimleri, kavramları incelemek ve açıklamak için sosyal bilimlerde yaygın olarak kullanılmaktadır. Fenomenoloji deseni; nitel araştırma yöntemi kapsamında, bireylerin aslında bildiği ama derin ve ayrıntılı bir fikir sahip olmadıkları olgulara yönelik yaşantı, algı ve bunlarla ilişkili anlamları belirlemeyi amaçlamaktadır. Fenomenoloji araştırmalarında, genel ve kesin sonuçlar ortaya çıkmayabilir. Ancak, olgunun iyi kavranmasına yardımcı olarak, teori ve uygulamaya ilişkin katkı sağlamaktadır. Fenomenoloji deseninde kullanılan veriler, araştırmada yer alan olgu ve olayların içinde olan, bunları aktarabilecek kişi veya topluluktan meydana gelmektedir (Yıldırım ve Şimşek, 2006). Fenomenoloji araştırmalarında, katılımciların olaylara, fenomenlere ve eylemlere hangi anlamları yükledikleri araştırılmaktadır. Araştırmanın fenomeni olan "okul yönetimine katılımı" rehber öğretmenlerin nasıl algıladıkları, hangi anlamları yükledikleri ve "okul yönetimine katılım" durumuna ilişkin bilgi, tecrübe ve beklentilerinin neler olduğunun belirlenmesi amaçlanmaktadır. Fenomenoloji yaklaşımında, nasıl ve neden sorularına yanıt aranmaktadır. $\mathrm{Bu}$ araştırmada da rehber öğretmenlerin okul yönetimine katılımlarının nasıl gerçekleştiği, etkilerinin neler olduğu, hangi değişkenlerden etkilendiği ve etkili katılım için neler yapılacağına ilişkin derin veriler elde edilmeye çalışılmıştır. Fenomenoloji yaklaşımını kullanmadaki esas amaç, katılımcıların olguyla ilgili deneyimlerini yansıtmalarıdır. $\mathrm{Bu}$ demektir ki, katılımcıların mutlaka çalışılan olguyla ilgili bir yaşantıları olmalıdır (Gliner, Morgan, \& Leech, 2015). Bu araştırmada, araştırmacilardan biri rehber öğretmen olarak görev yapmaktadır. Diğer araştırmacı ise, geçmişte on yıllık rehber öğretmenlik deneyimine sahiptir. Yani, araştırmada hem katılımcıların hem de araştırmacıların çalışılan olguyla ilgili bir yaşantıları bulunmaktadır. $\mathrm{Bu}$ durum, araştırmada gerçekçi yaşantıların elde edilmesine, araştırmanın tutarlılığına, daha derinlemesine verilerin toplanmasina ve analiz yapılmasına katkı sağlamaktadır. $\mathrm{Bu}$ araştırmada, alanda görevli rehber öğretmenlerin deneyimleri ve görüşlerinden yararlanılarak, okul yönetimine katılım hakkında derinlemesine bilgi sahibi olabilmek için nitel fenomenoloji deseninden yararlanılmaktadır.

\section{2. Çalışma Grubu}

Araştırmanın çalışma grubunu, 2019-2020 eğitim-öğretim yılında İstanbul'un Kartal ve Maltepe ilçelerindeki resmî kurumlarda görevli olan ve araştırmaya gönüllü olarak katılım sağlayan 31 rehber öğretmeni oluşturmaktadır. Katılımcıların belirlenmesinde nitel araştırmalarda kullanılan, amaçlı örnekleme yöntemlerinden kolay ulaşılabilir durum örneklemesi kullanılmıştır. Yıldırım ve Şimşek'in (2006) belirttiği gibi, amaçlı örnekleme yöntemi pek çok konuda, olay ve olguların tanımlanması, açıklanması ve yorumlanmasında fayda sağlamaktadır. Ayrıca, amaçlı örneklemede belli bir amaç doğrultusunda çalışılması nedeniyle genelleme yapılamaz ama örnekleme ilişkin daha derinlemesine ve kapsamlı analizler yapilabilir. Kolay ulaşılabilir durum örneklemesi yardımıyla, araştırmacılar kendilerine daha yakın olan ve kolaylıkla ulaşabilecekleri bir durumu, olayı tercih ederek, araştırmayı daha hızlı ve pratik 
olarak gerçekleştirebilmektedir. Yaygın olarak kullanılan bu yöntemin diğer yöntemlere göre daha az maliyetli olması avantaj sağlarken, sonuçlarının daha az genellenmesi ise dezavantaj oluşturmaktadır (Yıldırım ve Şimşek, 2006). Araştırmada, çalışma grubunu oluşturan okullara erişimin kolay olması, araştırmacılardan birinin bu bölgede görevli olması, verilerin elde edilmesinde kolaylık sağlamıştır. $\mathrm{Bu}$ nedenle, araştırmada kolay ulaşılabilir durum örneklemesinin tercih edildiği söylenebilir.

\subsubsection{Katılımcılara İlişkin Demografik Bulgular}

Araştırmanın bu bölümünde katılımcılara ilişkin demografik bilgilere yer verilmiştir. Katılımcıların tamamı resmî kurumlarda görev yapmaktadır.

Katılımcıların demografik özellikleri Tablo 1.'de yer almaktadir:

Tablo 1. Katılımcıların Demografik Özellikleri

\begin{tabular}{|c|c|c|}
\hline Demografik Özellik & Alt Boyut & (n) \\
\hline \multirow{8}{*}{ Yaş Aralığı } & $26-30$ & 4 \\
\hline & $31-35$ & 6 \\
\hline & $36-40$ & 6 \\
\hline & $41-45$ & 2 \\
\hline & $46-50$ & 4 \\
\hline & $51-55$ & 5 \\
\hline & 56 ve üstü & 4 \\
\hline & Toplam & 31 \\
\hline \multirow{3}{*}{ Cinsiyet } & Kadın & 20 \\
\hline & Erkek & 11 \\
\hline & Toplam & 31 \\
\hline \multirow{3}{*}{ Öğrenim Durumu } & Lisans & 26 \\
\hline & Yüksek Lisans & 5 \\
\hline & Toplam & 31 \\
\hline \multirow{6}{*}{ Meslekî kıdem } & $6-10$ y1l & 8 \\
\hline & $11-15$ y1l & 7 \\
\hline & $16-20 \mathrm{y} 11$ & 5 \\
\hline & $21-25$ y1l & 6 \\
\hline & $26-30 \mathrm{y} 1 \mathrm{l}$ & 5 \\
\hline & Toplam & 31 \\
\hline \multirow{7}{*}{ Görev Yapılan Kurum } & Bağımsız anaokulu & 1 \\
\hline & İlkokul & 9 \\
\hline & Ortaokul & 11 \\
\hline & Meslek lisesi & 1 \\
\hline & Akademik lise & 5 \\
\hline & $\begin{array}{l}\text { Rehberlik araştırma } \\
\text { merkezi }\end{array}$ & 4 \\
\hline & Toplam & 31 \\
\hline \multirow{5}{*}{ Mezuniyet Alanı } & PDR & 10 \\
\hline & Okul öncesi öğretmenliği & 3 \\
\hline & Özel eğitim öğretmenliği & 3 \\
\hline & Diğer alanlar & 15 \\
\hline & Toplam & 31 \\
\hline
\end{tabular}

Tablo 1. incelendiğinde, araştırmaya katılan rehber öğretmenlerin çoğunluğunun $(n=12), 31-40$ yaş aralığında bulunduğu ve genel olarak kadınlardan $(n=20)$ oluştuğu görülmektedir. Araştırmaya katılan rehber öğretmenlerin büyük bir bölümü $(n=26)$ lisans mezunu olup, meslekî kıdem bakımından çoğunluğu $(n=8) 6$ ile 10 yıl arasında değişen kıdeme sahiptir. Ayrıca, rehber öğretmenlerin çoğunluğunun $(n=11)$ ortaokulda görevli olduğu, büyük bir çoğunluğunun $(\mathrm{n}=21)$ ise PDR alanından farklı alanlardan (okul öncesi, özel eğitim ve diğer alanlar) mezun oldukları görülmektedir.

\subsection{Veri Toplama Arac1}

Araştırma kapsamında, verilerin elde edilmesinde araştırmacıların hazırladığı yarı yapılandırılmış görüşme formu kullanılmıştır. Görüşme formunda yaş, cinsiyet, öğrenim durumu, meslekî kıdem, görev yapılan kurum ve mezuniyet alanı gibi demografik özellikleri belirlemeye yönelik 6 soru yer almaktadır. Ayrıca, geçmişte okul yöneticiliği yapma durumu, okul yöneticiliğini tercih etme durumu ile okul yönetimine katılıma ilişkin kapalı uçlu 3 soru yer almaktadır. Görüşme formunda ise 6 açık uçlu soru yer almaktadır. Ekiz'in (2013) belirttiği gibi, yarı yapılandırılmış görüşmelerde, araştırmacılar soruları önceden hazırlamaktadır, ancak görüşme esnasında katılımcılara kısmen bir esneklik sağlanarak mevcut sorular yeniden düzenlenerek tartışılabilir. Veri toplama aracının oluşturulmasında, öncelikle konu ile ilgili alan yazın taraması yapılmıştır. Bu kapsamda, konu ile ilgili 10 açık uçlu sorudan oluşan bir taslak görüşme formu oluşturulmuştur. $\mathrm{Bu}$ görüşme formunun geçerliğini sağlayabilmek amacıyla 5 okul rehber öğretmeni ile pilot görüşmeler yapılmıştır. Pilot görüşmeler sonucu elde edilen veriler, uzman görüşleri ve önerileri de dikkate alınarak analiz edilmiş ve sorularda düzenlemeler yapılmıştır. Örneğin, taslak görüşme formunda yer alan bazı sorular (1. Okul yönetimine katılımın örgüt kültürüne etkileri nelerdir? 2. Okul yönetimine katılım ile ilgili yaşadığınız örnek olaylar nelerdir? 3. Okul yönetimine katılımda merkezî yönetimden kaynaklanan etkiler nelerdir? 4. Okul yönetimine katılım neden önemlidir?) pilot uygulama ve uzman değerlendirmeleri sonucunda görüşme formundan çıkarılmıştır. Eğitim bilimleri alanında uzman 3 akademisyenin görüşü sonrasında araştırmanın amacına uygun 6 soru tercih edilerek, görüşme formu oluşturulmuştur.

\subsection{Verilerin Toplanmas 1}

Araştırmada verilerin toplanmasında yarı yapılandırılmış bireysel görüşme tekniği kullanılmıştır. Bireysel görüşmeler için öncelikle araştırmaya katılmak isteyen gönüllü okul rehber öğretmenleri belirlenmiştir. Araştırma için Kırklareli Üniversitesi Bilimsel Araştırma ve Yayın Etiği Kurulundan 35523585-199-E.8726 sayılı Etik Kurulu Onayı alınmıştır. Araştırma, 2019-2020 öğretim yılında görüşmeye gönüllü olarak katılmayı kabul eden 31 rehber öğretmen ile gerçekleştirilmiştir. Görüşmeler, eğitim-öğretim faaliyetini aksatmayacak şekilde, katılımcıların uygun bulduğu yer ve zamanlarda, araştırma hakkında bilgi verilip, gönüllü katılım onayları alınarak gerçekleştirilmiştir. Görüşmeler 20 ile 50 dakika arasında gerçekleşmiştir. Araştırma verileri, katılımcıların tercihi doğrultusunda, görüşme esnasında tamamı yazılı olarak kayıt altına alınmıştır. Araştırmanın tutarlılığı için görüşme sonucunda elde edilen rehber öğretmen görüşlerinden doğrudan alıntılar yapılarak R1, R2, R3...şeklinde kodlanmış ve bulgular bölümünde sunulmuştur.

\subsection{Verilerin Analizi}

Araştırma verilerinin analizinde içerik analizi kullanılmıştır. Nitel veri analizi türleri arasından en çok tercih edilen yöntemlerden biri olan içerik analizi, Silverman'ın (2001; akt. Özdemir, 2019) da belirttiği gibi, ağırlıklı olarak görsel ve yazılı metinlerin analizinde tercih edilmektedir. Araştırmada, öncelikle katılımcıların okul yönetimine katılım durumu ile ilgili ifadeleri dokusal betimleme kapsamında 
belirlenmiş, ardından katılımcıların okul yönetimine katılım durumlarını etkileyen değişkenler, ortam, bağlam vb. ile ilgili görüşleri yapısal betimleme olarak ortaya koyulmuştur. Yıldırım ve Şimşek'in (2006) belirttiği gibi, nitel veri analizinde genellikle 4 aşama bulunmaktadır. Bunlar; verileri kodlama, temaları bulma, kodları ve temaları düzenleme, bulguları tanımlama ve yorumlamadır. Araştırmada verilerin analizi sürecinde bu aşamalar izlenmiştir. Öncelikle, araştırmacılar araştırma soruları ile ilgili verileri inceleyerek fenomenin (okul yönetimine katılım) katılımcılar tarafından nasıl deneyimlendiğine yönelik, önemli açıklamaları, alıntıları incelemişlerdir. Böylece, fenomene yönelik anahtar ifadeler listelenmiştir. Ardından, araştırmacılar bu anahtar ifadelerden hareketle temalara bağlı anlam kümeleri/grupları, alt temaları ve kodları oluşturmuşlardır. Kod ve temaların oluşturulmasında birincil olarak katılımcı görüşleri esas alınmış, ancak aynı zamanda dış kaynak olarak araştırma konusu ile ilgili alan yazın incelenmiş ve uzman görüşlerine başvurulmuştur. Araştırmacıların ilk aşamada ortaya koydukları tema ve kodlamalar, alan yazın taraması ve uzman görüşlerine göre yeniden düzenlenmiş ve bulgular bölümünde tablolar halinde sunulmuştur. Araştırma verilerine ilişkin yorum ve öneriler bu bulgulara göre gerçekleştirilmiştir.

\subsubsection{Inandirlcılık ve Tutarlilık}

Nitel araştırmalarda inandırıcılık ve tutarlılı̆̆ sağlamaya yönelik alınan bazı önlemler bulunmaktadır. Nitel araştırmalarda inandırıcılık, araştırmacıların araştırdıkları olguları mümkün olduğunca tarafsızca gözlemlemesidir. Araştırmacının bu süreçte esnek olması, inandırıcılık konusunda önemli bir kazanç sağlamaktadır. Böylece, araştırmacı gerekli gördüğü noktalarda ek sorular sorabilir ve plan dışında farklı görüşmeler yapabilir (Yıldırım ve Şimşek, 2006). Bu bağlamda, verilerin analizi sürecinde inandırıcılığg ve tutarlılığı sağlayabilmek için bazı aşamalar izlenmiştir. Öncelikle, bütün veri analiz süreci ayrıntılı bir şekilde raporlanmıştır. Araştırmada inandırıcılığı sağlamada, görüşme yoluyla katılımcılarla uzun süreli etkileşim sağlanmış, derin odaklı veriler toplanmış, görüşme formunun oluşturulması ile verilerin analizi sürecinde uzman desteği alınmıştır. Ayrıca, tutarlılı̆̆ı sağlamak amaciyla bulgular bölümünde görüleceği üzere, bulgular katılımcıların görüşleri ile doğrudan desteklenerek sunulmuş, verilerin kodlanması sürecinde araştırmacıların görüşlerinin tutarlılı̆̆ sonuçların sunulmasına özen gösterilmiştir. Yıldırım ve Şimşek'in (2006) belirttiği gibi, nitel olarak yürütülen araştırmalarda, araştırmacıların olaylara yönelik alg1 ve yorumları farklı olduğundan, farklı araştırmacıların yorumları farklı sonuçlar doğurmaktadır. Örneğin, araştırmacılar verilerin analizi sonucunda "demokratik okul kültürü" şeklinde bir tema oluşturmalarına rağmen, uzman görüşleri sonucunda bu temanın "katılımın etkileri" temasına bağlı olarak kodlanması önerilmiş ve bu şekilde işlem gerçekleştirilmiştir. $\mathrm{Bu}$ yüzden, araştırmacıların oluşturmuş oldukları kodlar ve temalar, araştırmacılardan farklı olarak alan uzmanları tarafından da tekrar oluşturulmuş ve elde edilen kod ve temaların büyük oranda benzer olduğu görülmüştür. Araştırmada tutarlılığı sağlamada, araştırmacıların elde ettiği bulgular, veri toplama araçları, kodlamalar, notlar, yazılar ve çıkarımlar, teyit incelemesi amacıyla, alan uzmanlarının görüşlerine sunulmuştur. Alan uzmanlarının eşleştirmeleri ile araştırmacıların eşleştirmeleri karşılaştırılmıştır. Kodlamanın güvenirliğini belirlemek amacıyla Miles ve Huberman'ın (1994, s. 64), [Güvenirlik = Görüş Birliği / (Görüş Birliği + Görüş Ayrılığı)] x 100, formülü uygulanmıştır. [Güvenirlik $=48 /(48+11)$ ] x 100= .81 ; işlemi sonucunda kodlayıcılar arasındaki uyum .81 olarak bulunmuştur. Kodlayıcılar arası tutarlılı̆̆ın \%70'ten büyük olması, kodlamanın tutarlı olduğunu doğrulamaktadır. Temalara bağlı belirlenen kodlar, daha sonra kendi içinde tekrar analiz edilerek temalarla ilişkilendirilmiştir (Bogdan, \& Biklen, 1998; Creswell, 2002). Daha sonra, katılımcılara ait görüşleri doğrudan belirten ifadeler verilmiş, kod ve temalar örneklendirilmiştir. Araştırmanın inandırıcılık ve tutarlılığını sağlamaya yönelik olarak veriler yorum katılmadan olduğu gibi verilmiştir. Verilerin analizine göre, 6 tema, 2 alt tema, 45 kod belirlenmiş ve verilerin analizi bu temalara göre gerçekleştirilmiştir. Ayrıca, araştırmanın inandırıcılığını sağlamak amacıyla; Creswell'in (2002) vurguladığı gibi, a) bulgular ilişkili olduğu duruma göre yorumlanmış, b) temaların iç tutarlılığına yönelik içsel homojenlik ve dişsal heterojenlik kriterleri esas alınmıştır. Araştırmanın inandırıcılığına yönelik olarak, katılımcıların görüşlerine bulgular bölümünde yer verilmiştir. Araştırmada ayrıca araştırmanın modeli, çalışma grubu, veri toplama aracı ve verilerin analizi gibi işlem basamakları yöntem bölümünde ayrıntılı olarak açıklanmış ve araştırmanın inandırıcılığı sağlanmıştır.

\subsection{Araştırmanın Sınırlılıkları}

$\mathrm{Bu}$ araştırma, rehber öğretmenlerin okul yönetimine katılım durumunu belirlemeye yönelik olarak, çalışma grubunda yer alan rehber öğretmen görüşlerinin nitel araştırma yöntemleri kullanılarak analiz edilmesi ile sınırlıdır.

\section{Bulgular}

Araştırmaya katılan rehber öğretmenlerden bir bölümü $(n=11)$, daha önce okul yöneticiliği yaptığını, bir bölümü $(n=20)$ ise, daha önce okul yöneticiliği yapmadığını belirtmiştir. Rehber öğretmenlerin çoğunluğu (n=22) okul yöneticiliği yapmak istemediğini belirtirken, bir bölümü $(n=8)$ okul yöneticisi olmak istediğini, bir katılımc1 ise bu konuda kararsız olduğunu belirtmiştir. Rehber öğretmenler $(\mathrm{n}=15)$, okul yönetimine yeterli katılımı sağladıklarını düşünmektedir. Ancak, bazı katılımcılar $(n=14)$ ise okul yönetimine yeterli katılımı sağlamadıklarını düşünmektedir. Bazı katılımcılar $(\mathrm{n}=2)$ ise bu konuda kararsız olduklarını belirtmiştir.

Araştırma verilerinin analizi sonucunda elde edilen temalar, Tablo 2.'de yer almaktadır.

Tablo 2. Okul Yönetimine Katılım Durumu

\begin{tabular}{lll}
\hline \multirow{2}{*}{$\begin{array}{l}\text { Rehber } \\
\text { Öğretmenlerin } \\
\text { Okul }\end{array}$} & Temalar & (f) \\
\cline { 2 - 3 } $\begin{array}{l}\text { Yönetimine } \\
\text { Katılım }\end{array}$ & Yönetime katılım & 77 \\
\cline { 2 - 3 } $\begin{array}{l}\text { Öneriler } \\
\text { Durumları }\end{array}$ & Katılımın etkileri & 67 \\
\cline { 2 - 3 } & Katılım yöntemleri & 63 \\
\cline { 2 - 3 } & Katılım engelleri & 55 \\
\cline { 2 - 3 } & Katılım alanları & 46 \\
\hline
\end{tabular}

Tablo 2'de görüldüğü gibi, rehber öğretmenlerin okul yönetimine katılım durumlarına ilişkin görüşleri 6 tema altında analiz edilmiştir. Rehber öğretmenlerin okul yönetimine katılıma ilişkin görüşleri sırasıyla, "yönetime katılım", "öneriler", "katılımın etkileri”, "katılım yöntemleri", "katılım engelleri" ve "katılım alanları" 
temalarına bağlı olarak belirtilmiştir. Tablo 2.'den elde edilen temalara bağlı olarak ortaya çıkan kodlar ve rehber öğretmen görüşleri, araştırma sorularına uygun olarak aşağıda tablolar halinde sunulmuştur.

Araştırmaya katılan rehber öğretmenlerin okul yönetimine katılımına ilişkin genel görüşleri Tablo 3 'te yer almaktadır.

Tablo 3. Okul Yönetimine Katılıma İlişkin Genel Görüşler

\begin{tabular}{lll}
\hline Tema & Kodlar & (f) \\
\hline & Gereklidir & 18 \\
\cline { 2 - 3 } & Sorunların çözümü & 12 \\
\cline { 2 - 3 } Yönetime & İ̧ birliği & 10 \\
\cline { 2 - 3 } Katılım & Karara katılıma & 10 \\
\cline { 2 - 3 } & Yönlendirme & 8 \\
\cline { 2 - 3 } & Bilgi alısverişi & 6 \\
\cline { 2 - 3 } & Destek olma & 6 \\
\cline { 2 - 3 } & Başarı & \\
\hline
\end{tabular}

Tablo 3. incelendiğinde, araştırmaya katılan rehber öğretmenlerin bir bölümü ( $\mathrm{f}=18$ ), okul yönetimine katılımın gerekli olduğunu, okul yönetimine katılımın sorunların çözümü bakımından önemli olduğunu $(\mathrm{f}=12)$, bir bölümü $(\mathrm{f}=10)$ ise, okul yönetimine katılımı, iş birliği ve karara katılma olarak değerlendirmektedir. Ayrıca, katılımcılar, okul yönetimine katılımı, yönlendirme ( $f=8)$, bilgi alışverişi $(f=7)$, destek olma $(\mathrm{f}=6)$ ve başarı $(\mathrm{f}=6)$ kavramları ile açıklamaktadırlar. Bu konuda bazı katılımcıların görüşleri şu şekildedir:

"Kesinlikle gerekli olduğunu düşünüyorum. Özel durumlu ögrencilerin bir anlamda hak savunucusu okullarda her zaman rehber ögretmenler olmaktadır. Okul yönetimi genel yönetim ile ilgilenirken ayrintı durumlarl, bu ister kaynaştırma eğitimi ile ilgili olsun, ister anne babası ayrı ya da vefat etmiş olan ögrenci olsun, alınan kararlarda, yapılan gezilerde ya da verilen notta bunu göz ardl edebilmektedir. Daha bütüncül yaklaşım, ögrencilerinin gelişimine ve hayat hikayesine hâkim bir rehber ögretmenin görüşleri ile să̆lanabilir. Sınıf değişikliğinden, davranıs değerlendirme kurulu sürecine, kriz yönetiminden okul gezilerine kadar, rehber ögretmenlerle iş birliği içinde olmak, yöneticilere kolaylık ve etkililik sağlayacaktır" (RI).

"Uzmanlı alanımızla ilgili konularda yönetime katılım să̆llyoruz. Bizden fikir sorulduğunda, iş birliği ve yönlendirme yapmaktayız. Yani, rehber ögretmenler görüssleri alınarak yönetime katılmal ve alınan kararlara fikirleriyle yön vermelidir" (R2).

"Rehberlik servisi, okul yönetiminin olmazlarından biridir. Ögrencilerle, okulla ilgili yapılan düzenlemelerde rehber ögretmenin öncelikli olarak fikri alınmalı. Kesinlikle katılması gerekiyor. Çünkü, insan ve çocuk psikolojisini bilen uzman kişi rehber ögretmendir” (R6).

"Rehberlik servisinin okulun yönetimine katılımının ĕgitim ögretim açısından oldukça büyük katkıları vardır. Yönetimde bulunan idarecilerin iş yükleri ă̆ırlı̆̆ nedeniyle, rehberlik servisi bu yükün özellikle ögrenci kismının büyük bir çoğunluğuna destek vermektedir" (R7).

"Rehberlik servisi toplantılarda fikirlerini beyan ederek okul yönetimine katılım sağlar. Katılım da sağlamalıdır. Çünkü, rehberlik servisi kendi alanıyla ilgili konularda okul yönetiminin ufkunu açabilir, işlerini kolaylaştırabilir” (R8).
"Rehberlik Servisinin okul içinde yönetime katılımından; okul içinde alınan kararlarda fikir alışverişini anlıyorum. Yönetime katkı să̆lamalıdır. Çünkü, ögrenci-veli-öğretmen hatta idare birlikteliğinde en yakın ve en etkili birimdir" (R12).

"Rehberlik Servisinin yönetime katılımından anladı̆̆ım şey, okul içinde özellikle yönetimsel kararlar alınırken sağlayacağı katkıdır. Özgür düşüncenin ifade edilmesi, tartışma ortamının yaratılması, üretken ve orijinal fikirlerin ortaya çıkması için okuldaki tüm personelin yönetimsel kararlarda payl olmalıdır. Ișleyiște okul personeline özelinde Rehberlik Servisine- fazlasiyla sorumluluk yüklenirken; planlama, koordinasyon, karar verme noktasında okul idaresinin genellikle baskıcı bir yaklaşım sergilediğini, kendi okulumda da başka kurumlarda çalışan arkadaşlarımdan edindiğim bilgilere göre de gözlemliyorum. Mutsuz bir şekilde, daha fazla çalışmamamı adına, okulda sürdürülen eğitim-ögretim faaliyetlerine evet rehberlik servisi olarak katkı sağlamalıyı"” (R18).

"Yönetime katılımdan okulun herhangi bir durumu için alınacak kararlar, ya da ortaya çıkan problemlerin çözümü için yapılması gerekenler veya okulun gelişimi için neler yapılacă̆ının belirlenmesi gibi durumlarda ögretmenlerin sorumluluk almasl gerektiğini anlyyorum. Rehber ögretmenler de okulun önemli bir parçası olduğu için yönetime katılmalarl gereklidir” (R13).

"Rehber öğretmenler tüm öğrencilerin başarl, ilgi, ilgisizlik, disiplin sorunları, gelişim davranışları ile ilgilendiklerinden okul yönetimine büyük ölçüde katıllyorlar. Okul yönetimine zaman zaman katkı sağlamaları gerekir. Çünkü, okul içi disiplin ya da çocuk gelişimi konularında destekleri gerekir" (R22).

Görüldüğü gibi, rehber öğretmenler okul yönetimine katılımı gerekli ve önemli görmektedirler. Okul yönetimine katılım ile öğrenci sorunları başta olmak üzere, pek çok alandaki sorunların çözümü, iş birliği, karara katılma ve öğrencilerin yönlendirilmesinin mümkün olabileceğini, yöneticilere pek çok konuda destek olunabileceği ve böylece okulun başarısına daha çok katkı sağlayabileceklerini düşünmektedirler.

Araştırmaya katılan rehber öğretmenlerin okul yönetimine katılım yöntemlerine ilişkin görüşleri, Tablo 4'te yer almaktadır.

Tablo 4. Okul Yönetimine Katılım Yöntemleri

\begin{tabular}{lll}
\hline Tema & Kodlar & (f) \\
\hline \multirow{4}{*}{ Katılım Yöntemleri } & Toplantılar & 22 \\
\cline { 2 - 3 } & Görüş bildirme & 9 \\
\cline { 2 - 3 } & Eğitim semineri & 7 \\
\cline { 2 - 3 } & Bireysel görüşmeler & 6 \\
\cline { 2 - 3 } & Grup çalışmaları & 5 \\
\cline { 2 - 3 } & Resmî bilgi talepleri & 4 \\
\cline { 2 - 3 } & Proje çalış̧aları & 2 \\
\hline
\end{tabular}

Tablo 4. incelendiğinde, rehber öğretmenlerin $(\mathrm{f}=22)$, genellikle toplantılar yoluyla okul yönetimine katılım sağladıkları görülmektedir. Ayrıca, rehber öğretmenler, görüş bildirme ( $\mathrm{f}=9)$, eğitim semineri $(\mathrm{f}=7)$, bireysel görüşmeler $(\mathrm{f}=6)$, grup çalışmaları $(\mathrm{f}=5)$, resmî bilgi talepleri $(\mathrm{f}=4)$ ve proje çalışmaları $(\mathrm{f}=2)$ yoluyla okul yönetimine katılım sağlayabildiklerini belirtmişlerdir. $\mathrm{Bu}$ konuda bazı katılımcıların görüşleri şu şekildedir: 
"Rehberlik servisinin okul yönetimine katılımı daha çok sözel görüş bildirimi aracılı̆̆ıla bizim okulumuzda gerçekleşmektedir. Idarecilerle ve dolayl olarak ögretmenler, konsültasyon ile ŞÖK toplantılarında BEP toplantılarında görüş bildirilmekte ve paylaşımlar yapılmaktadır ancak, yeterli değildir. Daha doğrusu kişiye, idare ile ilişkisine bağlıdır ve bu da bu konuda bir öznellik yaratmaktadır. En basitinden, danışmayı ego zedelenmesi olarak algılayan müdürler ve müdür yardımcllarl bu kaynaklarını etkin kullanamayacaklardır. Mümkün olsa, her hafta bir gün görüş alışverişi olabilecek düzenli toplantıların olması ama bu toplantıların esnek ve keyifli bir atmosferde gerçekleşmesi oldukça faydalı olabilir" (R1).

"Toplantılarla genel toplantılar, rehberlik yürütme kurulu, zümre toplantılarl, ögretmenler kurulu toplantısı (sene başı ve yll sonu), OGYE-Kurullar komisyonlarla katılım să̆lanmaktadır. Sürekli iş birliği ile her türlü karar mekanizmalart ile yeterlidir" (R5).

"Maalesef, her kurumda yönetime katılması söz konusu değildir. Mevcut durum yetersizdir. Daha çok, sıkıntı yaşanılan ögrenciler konusunda hizmet vermektedirler. Tek amacı bu değildir. Rehber öğretmenlerden gerçek manada istifade eden kurumumuz maalesef ki çok az" (R9).

"Daha çok özel çabalarl ile rehber ögretmenler okul yönetiminde kendilerine yer açmaya çalışırlar. Özel uzmanlık ve test yapılması halinde, ciddî yaptırımları bulunan 'adlî vakalar ve özel eğitim' gibi konularda katılım sağlayabildiklerini düşünüyorum. Bu katılım durumunun kriz anlarında değil, normal okul işleyişinde de olması gerektiğini düşündüğüm için yeterli bulmuyorum” (R18).

"Rehber öğretmenlerin yönetime katılımı pek gerçekleşmiyor. İdareciler 'Nöbet tutmayl' yönetime katılma sanıyor olabilirler. Okulla ilgili alınacak kararların ya da yapılacak uygulamaların çocuklarda (ögrencilerde), velilerde ya da ögretmenlerde psikolojik olarak yansımalarının neler olabileceği ile ilgili rehber ögretmenlerle istişare edilebilir" (Rl3).

“Okul yönetimine katılım, okul müdürü, müdür yardımcıları ve ĕger varsa kurum sahibinin (özel okulda) bakıș açısı ile yakından ilişkili bir durum. Katılımı için desteklenen bir rehberlik öğretmeni daha objektif ve ögrenci yararına fikir beyan ederek yönetime katılabilir. Rehber ögretmenler, genellikle ögrencileriyle ilgili konularda kendilerine danışıldı̆̆ında, yeterli şekilde katılım sağlayabiliyorlar" (R19).

"Rehberlik servisinin yönetime katılım sağlaması için idarenin olumlu davranış içinde olması, iki birimin fikir alışverişi yapabilmesi gerekir. Öğrencilerle ilgili çalışmalar, ögretmenlere uygulanacak seminer, bireysel görüşmeler ve grup çalışmaları, bilgilendirmeler ve velilere yapılan toplant, seminer $v b$. gibi çalışmalarıla katkı sağlayabiliyorlar. İdare ile sağllkl bir iletişim sağlarsa yeterli ve verimli olabilir" (R23).

"Rehberlik servisinin müşavirlik hizmeti vererek kendi uzmanlık konularında yönetime katılabilir. Toplant, kurul, komisyonlar ve bireysel görüşmeler. Rehberlik servisi idarenin bakış açısına bağlı her konuda destek sağlayabilir ya da okulda görmezlikten atıl bir servis konumuna da gelebilir. Rehberlik servisinin çalışmasına ve idarenin bakış açısına göre değişir. Bazı okullarda yeterlidir, bazı okullarda kişilik savaşları halen yapıldiğından yetersizdir" (R31).

Rehber öğretmenlerin okul yönetimine katılım yöntemlerine ilişkin görüşleri incelendiğinde, genellikle rutin toplantılar (öğretmenler kurulu toplantıları, şube ve zümre öğretmenler kurulu toplantıları, rehberlik yürütme komisyonu toplantıs1, kurul ve komisyon toplantıları vb.) başta olmak üzere, görüş bildirme, eğitim seminerleri ile bireysel görüşmeler ön plana çıkmaktadır. Ancak, bu yöntemlerin okula ve yöneticilerin tutumuna göre farklılık gösterdiği ve uygulama bakımından yeterli olmadığı, bazı sorunlarla karşılaşıldığı belirtilmektedir.

Rehber öğretmenlerin okul yönetimine hangi alanlarda katılım sağlayabildiklerine ilişkin görüşler, Tablo 5.'te sunulmuştur.

Tablo 5. Okul Yönetimine Katılım Alanları

\begin{tabular}{lll}
\hline \multirow{2}{*}{ Tema } & Kodlar & (f) \\
\hline \multirow{4}{*}{ Katılım Alanları } & Danışmanlık & 12 \\
\cline { 2 - 3 } & Ö̆ğrenci problemleri & 9 \\
\cline { 2 - 3 } & Özel eğitim öğrencileri & 8 \\
\cline { 2 - 3 } & Bilgilendirme çalışmaları & 6 \\
\hline
\end{tabular}

Tablo 5. incelendiğinde, rehber öğretmenlerin genellikle danışmanlık (f=12) alanında okul yönetimine katılım sağladıkları görülmektedir. Rehber öğretmenlerin okul yönetimine katılım sağladıkları diğer alanlar ise, öğrenci problemleri ( $\mathrm{f}=9)$, özel eğitim öğrencileri ile yapılan çalışmalar ( $\mathrm{f}=8$ ) ve bilgilendirme çalışmaları $(\mathrm{f}=6)$ olarak belirtilmiştir. $\mathrm{Bu}$ konuda bazı katılımcıların görüşleri şu şekildedir:

"Rehberlik servisi yönetime katılmiyorlar. Sadece kaynaştırma ögrencileriyle ilgili çalışmalar yapmaktadırlar" (R4).

“Rehberlik servisi özel görüşmeler yaparak hem ögrrencilere hem de velilere destek verir. Bazı problemlerde ise yönlendirmeler yaparak, ögrencilerin problemlerini çözme, düzenli ders çalışma, akademik başarılarının artırılmasını sağlamalıdır" (R7).

"Rehberlik servisi direkt değil, dolayl olarak okul yönetimine katkl să̆lar. Bu katkl, ögretmen ve veli bilgilendirmeleriyle gerçekleşmektedir. Yeterlidir" (R 8).

"Haftalı ve aylık olmak üzere değerlendirme toplantısı yaparak idare ile yönetime katılımı gerçekleştiriyoruz" (R12).

“Görüşmelerde genelde öğrencilerin ders çalışması, olumsuz davranışlar ile öğrencide gördüğ̈̈müz değişiklikler olduğunda veli ile görüşüp, rehber ögretmenle görüşmesi sağlanmakta, çözüm bulunmast, velileri dinleyerek bilgilere ulaşmaya çalışmaktadır” (R20).

"Projeler, veli-öğrenci toplantılart, sosyal sorumluluk çalışmalart, ĕgitsel değerlendirme, rehber ögretmen, veli ve yönetici arasındaki sağlam iş paylaşımı ile etkin ve destekleyici olmalıdır” (R24).

"Kurul toplantılarında bulunuyorlar. Öğretmen, veli ve ögrenci ilişkileri konusunda görüş bildiriyorlar ancak yeterli olmuyor” (R27).

"Öğrencilerin davranış problemleri olduğunda rehber ögrretmenin görüşleri okulda dikkate alınıyor” (R28). 
Görüldüğü gibi, rehber öğretmenler genel olarak uzmanlık alanları olan danışmanlık alanı başta olmak üzere, öğrenci problemlerinin çözümü ile özel eğitim öğrencilerine yönelik çalışmalar ve değişik konulardaki bilgilendirme çalışmaları ile okul yönetimine kısmen katılım sağlayabildiklerini belirtmişlerdir.

Araştırmaya katılan rehber öğretmenlerin okul yönetimine katılımlarının etkilerine ilişkin görüşleri Tablo 6.'da sunulmuştur.

Tablo 6. Okul Yönetimine Katılımın Etkileri

\begin{tabular}{|c|c|c|c|}
\hline & $\begin{array}{l}\text { Tema } \\
\text { Katılımın Etkileri }\end{array}$ & Kodlar & (f) \\
\hline \multirow{11}{*}{ 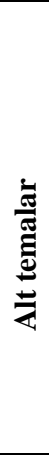 } & \multirow{7}{*}{ Olumlu Etkiler } & $\begin{array}{l}\text { Demokratik okul } \\
\text { kültürü }\end{array}$ & 12 \\
\hline & & Destek olma & 10 \\
\hline & & Sorunların çözümü & 5 \\
\hline & & Başarının artması & 5 \\
\hline & & Kalitenin Sağlanması & 4 \\
\hline & & Hizmetlerin etkinliği & 4 \\
\hline & & Okula güven & 3 \\
\hline & \multirow{4}{*}{ Olumsuz Etkiler } & Rol karmaşası & 7 \\
\hline & & Yanlış algılamalar & 5 \\
\hline & & İş yükü artış1 & 4 \\
\hline & & Alan dış1 talepler & 4 \\
\hline
\end{tabular}

Tablo 6. incelendiğinde, rehber öğretmenlerin okul yönetimine katılımlarının olumlu ve olumsuz etkileri olabileceği görülmektedir. Rehber öğretmenlerin okul yönetimine katılımlarının en önemli olumlu etkisi olarak, demokratik bir okul kültürü ( $\mathrm{f}=12$ ) oluşmasına katkısı olacağ belirtilmiştir. Ayrıca, veli, öğretmen, öğrenci, yönetici ve çevreye destek olma ( $\mathrm{f}=10)$, okulda sorunların çözümü $(\mathrm{f}=5)$ ve başarının artması $(\mathrm{f}=5)$, rehberlik hizmetlerinin daha etkin yürütülmesi ( $\mathrm{f}=4$ ) ve kalitenin sağlanması $(\mathrm{f}=4)$, veli, öğrenci ve çevrenin okula daha fazla güven duyması $(\mathrm{f}=3)$ şeklinde belirtilmiştir. Tablo 6'da görüldüğü gibi, rehber öğretmenlerin okul yönetimine katılımlarının olumsuz etkileri, rol karmaşası $(\mathrm{f}=7)$, yanlış algılamalar $(\mathrm{f}=5)$, alan dişı talepler $(\mathrm{f}=4)$ ve iş yükü artışı $(\mathrm{f}=4)$ olarak belirtilmiştir. Konu ile ilgili bazı katılımcıların ifadeleri şu şekildedir:

"Rehberlik servisinin okul yönetimine katılımlarının yalnızca olumlu etkileri olacaktır. Kendiliğinden çalışan, sürekli kendini geliştiren, insanların hikayelerini dinleyen, önemseyen ve notlar alan bir rehber ögretmen okuldaki ögretmenlerin, velinin, okul ihtiyaçlarının daha çok farkında olan bireydir. Aslında bir anlamda okulda kaliteyi sağlamak ve korumak rehber ögretmenin görüsleri ile daha mümkün olacaktır. Çünkü, yönetim çoğu zaman nicelik ile uğraşmakta ve bu işler esnasinda özel her durum yeterince vurgulanmayabilir” (R1).

"Rehber ögretmenler olası bir sorunda, okul yöneticilerinin, ailenin, çocukların ve ögrretmenlerin en büyük yardımcısı konumundadır. Okul yönetimine ne kadar etkin katılırlarsa okul içerisinde alınacak kararlar daha sağlıkl olacaktır. Rehberlik servisi sürekli bilgilendirme yaptı̆̆ sürece, okul yönetimine katılım düzeyleri, okul kültürünü üst düzeyde etkiler. Öğrenciler, veliler ve okul çalışanları arasında değerlendirmeler yapıldı̆̆ında sorunlar asgari noktada azalmaktadır” (R6).

"Problem yaşanması muhtemel alanlar, önceden tespit edilip odak çalışmalar yapıldığında, yönetime katılan bir rehberlik servisinin olduğu kurumda sorun yaşanma ihtimali, çatışma olması ihtimali çok düşüktür. Okulda yapılan çalışmalar, çalışanların ve hizmet alanların önceliğine göre yapıldı̆̆ında, herkeste aidiyet duygusu gelişmiştir. Bu nedenle, yüksek verim söz konusudur. Bu arada roller karlşabilir. Bu duruma dikkat edilmelidir” (R9).

"Okul yönetimine rehberlik servisinin dengeli katılımı zengin ve özgün bakış açılarl katar. Bununla birlikte okul yönetiminde işleyişe fazlaca katılım meslekî duruşumuzun veli, öğretmen ve ögrenci nazarında yanlış algllanmasına sebep olur diye düşünüyorum” (R18).

"Okula, yöneticilere, ögrencilere ve velilere neyi nasıl yapacaklarl konusunda yol gösterici olacağı için olumlu bir etki oluşturacaklardır. Bu durum, sadece rehberlik hizmetlerine daha fazla iş düşeceği için onların iş yükünü artıracaktır. Öğrenci ve veli profilini uzman bir görüş ile değerlendirdiği için okul kültürüne olumlu yönde etkileri olacaktır. Katılım düzeyi arttıkça okul kültürüne etkileri de doğru orantılı artacaktır”, (R15).

"Rehberlik servisinin okul yönetimine katılım düzeyi arttıkça okulun gri, soluk, diplomatik yüzü yerini daha neşeli, keyifli, çılgın ve yenilikçi bir anlayışa bırakır diye düşünüyorum" (R18).

"Öncelikle rehberlik ögretmeni sürece dahil olduğunda kendisini daha değerli hissedip, alınan kararlara katılımda daha istekli ve aktif rol alabilecektir. Ayrica, yönetimin bir parçası olmak, işine de olumlu yansıyacaktır. Okul kültürünü olumlu etkiler. Ögrenci ve okul sorunlart daha iyi tespit edilebilir. Fakat, idarî kadro gibi görülmemeli ve rehberlik servisinden korkulması gibi bir anlayış ve ortam oluşturulmamalıdır” (R29).

"Okul yönetimine katılımda bazı durumlarda meslekî sınırlar gözetilmeksizin talepler ve beklentiler olabilmektedir (idare, ögretmen, veli tarafindan)" (R30).

Görüldüğü gibi, rehber öğretmenlere göre, okul yönetimine katılımın en önemli olumlu etkisi demokratik okul kültürünün oluşması, karşılaşılan sorunlarda yönetime destek olma ve sorunların çözülmesi ile başarının artmasıdır. Ancak, özellikle PDR mezunu rehber öğretmenlere göre, okul yönetimine katılım meslekî ilkeleri ve sınırları ortadan kaldırabilir, rol karmaşası, yanlış algılamalar ve alan dışı talepler ile iş yükü artışına neden olabilir.

Rehber öğretmenlerin okul yönetimine katılım engellerine ilişkin görüşler, Tablo 7'de sunulmuştur.

Tablo 7. Okul Yönetimine Katılım Engelleri

\begin{tabular}{lll}
\hline Tema & Kodlar & $(\mathbf{f})$ \\
\hline \multirow{4}{*}{$\begin{array}{l}\text { Katılım } \\
\text { Engelleri }\end{array}$} & Okul yöneticileri & 16 \\
\cline { 2 - 3 } & Rehber öğretmenler & 12 \\
\cline { 2 - 3 } & Önyargılar & 6 \\
\cline { 2 - 3 } & Diğer öğretmenler & 4 \\
\cline { 2 - 3 } & Rehberlik hizmetleri & 3 \\
\cline { 2 - 3 } & Veliler & 2 \\
\cline { 2 - 3 } & Çevre & \\
\hline
\end{tabular}

Tablo 7. incelendiğinde, rehber öğretmenlerin okul yönetimine katılım engellerinin okul yöneticileri $(f=16)$, rehber öğretmenler $(\mathrm{f}=12)$, ön yargilar $(\mathrm{f}=6)$, diğer ögretmenler ( $\mathrm{f}=4)$, veliler $(\mathrm{f}=3)$, rehberlik hizmetleri $(\mathrm{f}=3$ ) ve 
çevre (f=2) gibi faktörlerden kaynaklandığı belirtilmiştir. Bu konuda bazı katılımcıların görüşleri şu şekildedir:

"İdarecilerin egosu, iş birliğine yanaşmayan üslubu ve rehberliği bilmemekten kaynaklanan bilgi eksikliği" (R1).

"Okul içerisindeki rehber ögretmenin fazla iş yükü, okul yöneticilerinin olumsuz tavirlarl, okul ögretmenlerinin olumsuz tavirlarl, ögretmen sayısının eksikliği, öğrenci sayısının fazla, rehber ögretmen sayısının az oluşu, rehber ögretmenin alanına hâkim olamaması" (R5).

"Rehber ögrretmenlerin görüşlerine önem verilmeyen bir idare anlayıșının olması katılımı engelleyebilir. Okul yönetiminin rehberlik anlayışının düzeyi ile orantılı bir durumdur. Eğer yeterli ölçüde bu anlayış yoksa, idareciler bilinçsiz ve ögretmenler rehberliğe önem vermiyorlarsa katılımı zorlayıcı bir durum ortaya çıkar" (R3).

"Yöneticinin otokrat tutumu, yönetişim değil yönetim anlayışını benimsemesi, Rehber ögretmenlerin suya sabuna dokunmama isteği, Yönetici ve rehber ögretmenin mesleki tükenmişlik sendromu yaşlyor olmast, Meslekte geçen uzun yıpratıcı yıllar, Çevrenin çalışmaları olumlu desteklememesi, yapılan çalışmaların istenilen sonucu vermemesi üzerine yılma durumu” (R9).

"Rehberlik Servisinin çalışma alanları konusunda sınır ihlalinin yapılması; bazen bizim işimiz olmayan şeyleri bizden yapmamızı beklemeleri, okul yönetiminin Rehberlik Servisine ve bu alana gereken önemi ve hassasiyeti göstermemesi, desteklememesi, kul yönetiminin Rehberlik Servisinin kendi içinde bă̆ımsız olan çalışmalarını ve aileler üzerindeki yöneltme etkisini "rakip gibi”" algllamasl” (R12).

"Rehberliğin ne olduğunun henüz tam anlaşılamamış olması, yüklenen evrak sorumluluklarından dolayı vaktinin çoğunu bunlar için kullanan rehberlik servisinin okul yönetimine ayıracak fazla zamanının olmaması" (R14).

"En başta okul yönetimlerinin kendileri rehberlik hizmetlerini angarya iş olarak gören zihniyetler olduğu müddetçe okul yönetimine katılımlarl zor olacaktır. Rehberlik hizmetleri denince akla yazılması gereken evraklar doldurulmasl gereken formlar, raporlar v.s geliyor. Çok fazla evrak işleri var. Dolayısıyla bu kadar fazla evrak işi yapmak rehberlik hizmetlerinin hem çok fazla vaktini allyor hem de performansını düşürüyor" (R15).

"Rehber öğretmenin isteksiz olması, kişisel özellikleri veya geçmişte yaşadiğı olumsuz çalışma koşulları da yönetime katılmayl engeller" (R19).

"Çalışmaların somut dönütlere dönüşmemesi yani, çalışmıyorlar imajını doğurması. Rehberlik birimlerinin motivasyonlarının bu sebeplerden çabuk düşmesi ve geri çekilmeleri. Paydaşlık adı altında farklı anlamsız görevler yüklenilmesi" (R24).

"Makam mevki hastalı̆̆l, var olan yöneticilerin çıkarları olduğu için deneme yanılma yöntemiyle yöneticilik olmamal, olumsuz yönetici ve öğretmen tutumlarl, rehber ögretmenlerin istenmeyen tutumlarl, rehberlik etme ve rehberlik talebi kültürünün topluma yerleşmemiş olması, meslekî yetersizlik, alan dışı atamalar katılımı olumsuz etkiler" (R25).
"İdarecilerin rehberlik servisinin işleyişine hâkim olmaması. $\mathrm{Bu}$ konuda gelenekselci olmalart ve iş birliği yapmaktan kaçınmalarl” (R28).

Tablo 7'de görüldüğü gibi, rehber öğretmen görüşlerine göre, okul yöneticilerinin ilgisizliği, bilgisizliği ile olumsuz tutum ve davranışları, okul yönetimine katılımın en önemli engellerinden biridir. Ayrıca, rehber öğretmenlerin tutum ve davranıșları, diğer öğretmenler ve velilerin rehberlik hizmetlerine gereken önemi vermemesi, bilgi eksiklikleri ve olumsuz tutumları da okul yönetimine etkili katılımı engellemektedir.

Rehber öğretmenlerin okul yönetimine etkili katılım sağlamalarına yönelik öneriler Tablo 8.'de sunulmuştur.

Tablo 8. Okul Yönetimine Etkili Katılım İçin Öneriler

\begin{tabular}{lll}
\hline Tema & Kodlar & (f) \\
\hline & Okul yöneticilerinin eğitilmesi & 17 \\
\cline { 2 - 3 } & Yasal düzenlemeler yapılması & 14 \\
\cline { 2 - 3 } & Rehberlik hizmetlerinin düzenlenmesi & 12 \\
\cline { 2 - 3 } Öneriler & Çalışma koşullarının iyileştirilmesi & 8 \\
\cline { 2 - 3 } & Rehber öğretmen ihtiyacının karşılanması & 6 \\
\cline { 2 - 3 } & Tüm çalışanların eğitilmesi & 5 \\
\cline { 2 - 3 } & PDR toplantılarının aylık olarak düzenlenmesi & 3 \\
\cline { 2 - 3 } & Okul-veli-çevre ilişkilerinin geliştirilmesi & 2 \\
\hline
\end{tabular}

Tablo 8. incelendiğinde, rehber öğretmenlerin okul yönetimine daha etkili bir şekilde katılım sağlayabilmeleri için sırasıyla, okul yöneticilerinin eğitilmesi ( $\mathrm{f}=17)$, yasal düzenlemeler yapılması $(\mathrm{f}=14)$, rehberlik hizmetlerinin düzenlenmesi $(\mathrm{f}=12)$, çalışma koşullarının iyileştirilmesi $(\mathrm{f}=8)$, rehber öğretmen ihtiyacının karşılanması ( $\mathrm{f}=6$ ), tüm çalışanların eğitilmesi ( $\mathrm{f}=5)$, PDR toplantılarının aylık olarak düzenlenmesi $(\mathrm{f}=3)$ ve okul-veli-çevre ilişkilerinin geliştirilmesi ( $\mathrm{f}=2$ ) şeklinde öneriler belirtilmiştir. Konu ile ilgili bazı katılımcıların ifadeleri şu şekildedir:

"Haftalı olarak idarecilerin ve rehber öğretmenlerin katıldığl görüş̧ alışveriş toplantıları, olumlu idare-rehber öğretmen ilişkisini destekleyen politikalar, rehberlik servisinin bu anlamda katılımının faydalarını gösteren seminerler yapllabilir" (R1).

"Idare ve rehber ögretmenler arasında iş birliği ve iletişimin olmasl, idarenin olumlu bir rehberlik anlayışına sahip olması, bu konuda idarecilere eğitimler verilmesi, Rehberlik Hizmetleri Yönetmeliğinde görev tanımımızın açık ve net olmasl, bu konuda okul yöneticilerinin bilgilendirilmesi yararlı olacaktır (okul müdürünün verdiği diğer görevleri yapar maddesi)" (R2).

"Yönetmeliklerde rehber ögretmenler için gerekli tanımlamalar yapılmıştır. Ancak, okul yönetimlerinin yeterli bilgiye sahip olmamass ve sadece problemli ögrenciyle ilgilenir önyargıları olması sonucu etkilemektedir” (R5).

"Rehberlik hizmetlerinin düzenli olarak yürütülebilmesi için yönetimin desteklemesi, uygun ortamları hazırlaması gerekmektedir” (R10).

“Veli, okul ve öğretmen iş birliği içerisinde olmalıdır” (R11).

"Rehber öğretmenin çalışması desteklenirse, çalışma ortamlarl rahat olursa etkili katılım sağlayabilirler” (R20).

"Rehberlik biriminin kendini öğrenciye ögrretmene ve veliye çok iyi anlatması ve aktif olması gerekli. Toplumsal alana 
somut olarak dokunmadı̆̆ımız hiçbir şey, işe yarar değil. Kurum içi rehberlik çalışmaları yapılması. Rehberlik odasından çıklarak, veliye, okula, öğretmene, çaycıya, güvenliğe dokunulmast, sosyal çevrenin okula katılımı noktasında işbirlikçi olunması” (R24).

"Okul müdürü ve diğer okul yöneticileri bu noktada eğitilerek farklı bakış açısı kazandırılmalıdır. Bakış açısı değişmezse, okul rehberlik servisleri atıl olmaya devam eder" (R25).

"Yıllık çalışma planlarına aylık toplantı haftaları eklenebilir. Okul yönetiminden haftalık veya aylık rehberlik servisi ile yaptıkları toplantı konularının raporlart istenebilir" (R26).

"Rehberlik ögretmenleri sınırlarını bilmeli, meslekî yönden donanıml olmall ve idareciler rehberlik servisleri konusunda bilinçlendirilmelidir" (R29).

Rehber öğretmen görüşleri incelendiğinde, okul yönetimine etkili katılım için okul yöneticilerinin rehberlik hizmetleri ile ilgili olarak yasal ve pedagojik bakımdan yetiştirilmesine ihtiyaç bulunmaktadır. Ayrıca öğretmenler, veliler, öğrenciler ve tüm çalışanların rehberlik hizmetleri konusunda yetiştirilmesi, bilinçlendirilmesi, toplumsal farkındalık kazandırılması, rehber öğretmenlerin çalışma koşullarının yasal ve pedagojik anlamda geliştirilmesi önerilmektedir.

Araştırma bulgularında görüldüğü gibi, rehber öğretmenler okul yönetimine etkili olarak katılım sağlayamamakta, bu konuda çözüm bekleyen pek çok engelle karşılaşmakta ve okul yönetimine etkili katılım için değişik alanlarda bazı öneriler belirtmektedir.

\section{Sonuç ve Tartışma}

Araştırmanın genel sonuçlarına göre, rehber öğretmenler okul yönetimine etkili olarak katılamamaktadır. Sorunların çözümüne katkı sağlaması, iş birliği ve kararlara katılma bakımından okul yönetimine katılım gerekli ve önemli görülmektedir. Okul yönetimine katılım, genellikle toplantılarda görüş bildirme şeklinde gerçekleşirken, yönetime katılım alanı olarak ise danışmanlık ve öğrenci problemlerinin çözümü olarak ortaya çıkmaktadır. Ayrıca, okul yönetimine katılım, demokratik okul kültürünün oluşması ve ilgililere destek sağlama bakımından olumlu katkılar sağlarken, rol karmaşası yaşanmasına neden olmaktadır. Okul yönetimine katılımdaki en önemli engel, okul yöneticilerinin olumsuz tutum ve davranışları ile bilgi eksikliklerinden kaynaklanmaktadır. Ayrıca, rehber öğretmenlerin de ilgisizliği, isteksizliği ve yetersizliği okul yönetimine katılımı olumsuz etkilemektedir. $\mathrm{Bu}$ sorunlara karşı okul yöneticilerinin eğitilmesi, yasal düzenlemeler yapılması, rehberlik hizmetlerinin düzenlenmesi ve çalışma koşullarının iyileştirilmesi önerilmektedir.

Rehber öğretmenlerin araştırma sorularına verdikleri cevaplar, yaş, cinsiyet, öğrenim durumu, meslekî kıdem ve görev yapılan kurum gibi demografik özelliklerine göre farklılık göstermemektedir. Ancak, rehber öğretmenlerin görüşlerinin mezuniyet alanlarına göre farklılıklar gösterdiği görülmektedir. Özellikle, okul yönetimine katılım yöntemi, katılım alanları, katılımın etkileri ile katılımı etkileyen değişkenlere yönelik görüşler farklılaşmaktadır. Örneğin, araştırmaya katılan rehber öğretmenlerin genel olarak PDR alanı dışından mezun oldukları dikkate alındığında, PDR alanından mezun olan ve 20 yıl kıdeme sahip olan bir katılımcının "özellikle alan dışı rehberlik ögretmenleri gizli müdür yardımcısı gibi çallşlyor. İdare bu durumdan memnun, meslektaşlar ise mutsuz, bu durum okul yönetimine katılım değil, aslî işini gereği gibi yapmamak ve alana yönelik olumsuz algllamalar oluşturmaktır", ifadesi, farklı alan mezunlarının rehber öğretmen olarak istihdam edilmelerinin gerek okul yönetimine katılımı, gerekse meslekî sınırları ortadan kaldırarak, rehberlik faaliyetlerinin etkili yürütülmesini olumsuz etkileyen, böylece rehber öğretmenlere alanları dışında görev ve sorumluluk verilmesine zemin hazırlayacak bir faktör olabileceği ihtimalini güçlendirmektedir. Araştırma sonucunda mezuniyet alanına göre, PDR alanı mezunu rehber öğretmenler, okul yönetimine katılımı sorunların çözümü, iş birliği ve kararlara katılım bakımından gerekli görürken, alan dışından mezun olan rehber öğretmenler ise, genel olarak bilgi alışverişi ve okul yönetimine destek olma bakımından gerekli görmektedir. Alan mezunu rehber öğretmenler, okul yönetimine katılım yöntemi olarak toplantılar, eğitim semineri ve görüş bildirmeyi belirtirken, alan dişından mezun olan rehber öğretmenler ise bireysel görüşmeler, resmî bilgi talepleri ve proje çalışmalarını belirtmişlerdir. Okul yönetimine katılım alanlarında, alan mezunu rehber öğretmenler genellikle danışmanlık, öğrenci problemleri ve özel eğitim öğrencileri ile yapılan çalışmaları belirtirken, alan dışından mezun olan rehber öğretmenler ise, genellikle bilgilendirme çalışmaları ve öğrenci problemlerini belirtmişlerdir. $\mathrm{Bu}$ sonuçlar da göstermektedir ki, rehber öğretmenlerin mezuniyet alanları, okul yönetimine katılıma ilişkin görüşleri ile okul yönetimine katılım alanlarını doğrudan etkileyen önemli bir değişkendir. Örneğin, alan dışından mezun olan rehber öğretmenlerin psikolojik danışmanlık ve özel eğitim öğrencileri ile yapılan çalışmalar dışındaki bilgilendirme çalışmaları ve öğrenci problemleri ile ilgili alanlarda daha çok katılım sağladıklarını belirtmeleri, alana yönelik bilgi, beceri, tutum ve formasyonlarının yeterli olmadığı, bu konularda yetiştirilmeleri gerektiği, bu nedenlerle alan diş1, genel rehberlik faaliyetlerini ön plana aldıkları şeklinde yorumlanabilir. Okul yönetimine katılımın etkileri olarak, alan mezunu rehber öğretmenlerin tamamı, okul yönetimine katılımın olumsuz etkileri (rol karmaşası, yanlış algılamalar, iş yükü artışı, alan dışı talepler) olabileceğini belirtmişlerdir. Bu durum, alanın gerektirdiği meslekî ve etik ilkelerin ihlal edileceğine yönelik kaygıdan ve alan dişından mezun olan rehber öğretmenlerin bu konudaki olumsuz tutum ve davranışlarından kaynaklanabilir. Alan dışından mezun olan rehber öğretmenler ise, okulun yönetimine katılımın etkileri olarak veli, öğretmen, öğrenci, yönetici ve çevreye destek olma, okuldaki sorunların çözümü ve başarının artması, olarak belirtmişlerdir. Ayrıca, alan mezunu rehber öğretmenler, okul yönetimine katılım engelleri olarak genellikle, okul yöneticileri, rehber öğretmenler ve önyargıları belirtirken, alan dışından mezun olan rehber öğretmenler ise genel olarak, veli, çevre, diğer öğretmenler ile rehberlik hizmetlerini belirtmişlerdir. Görüldüğü gibi, mezuniyet alanı rehber öğretmenlerin okul yönetimine katılımlarına yönelik görüşleri üzerinde etkili olan en önemli değişken olarak ortaya çıkmaktadır. Bu sonuçtan hareketle, tüm öğretim kademelerinde istihdam edilecek rehber öğretmenlerin mutlaka alan mezunu olmalarına özen gösterilmesi, bu konuda yasal düzenlemeler yapılması, alan dışından atama ve görevlendirme yapılmaması, farklı alanlardan mezun olan mevcut rehber öğretmenlerin ise mutlaka PDR alanında uygulamalı meslekî 
gelişim eğitimine alınması ihtiyacı bulunduğu söylenebilir. $\mathrm{Bu}$ sonuçlar, okul yöneticileri ile diğer öğretmenlerin de PDR alanında eğitilmelerinin önemli ve gerekli olduğunu ortaya koymaktadır. Ayrıca, rehber öğretmenlerin lisansüstü öğrenim görme oranının oldukça düşük olması 'kapsamlı olarak araştırılması gereken bir durum olmakla birlikte', meslekî gelişimlerini olumsuz etkilemiş olabilir. Katılımcıların kıdeminin genel olarak 6 yıldan fazla olmasının ise araştırmada daha zengin verilerin elde edilmesine katkı sağladığ 1 belirtilebilir.

Araştırmada, katılımcıların kapalı uçlu sorulara yönelik görüşlerinin analiz sonuçlarına göre, rehber öğretmenlerin çoğunluğu, daha önce okul yöneticiliği yapmadığını ve gelecekte de okul yöneticiliği yapmak istemediğini belirtmiştir. Araştırma sonuçları ile benzer şekilde, Günay ve Özbilen'in (2018) araştırma sonuçlarına göre, öğretmenlerin çoğunluğu okul yöneticiliği yapmak istemediklerini belirtmişlerdir. Gerekçe olarak ise, yöneticilikte meslekî doyumun sağlanamaması, mesai saatlerinin ve sorumluluğun fazla olması gösterilmiştir. Bingül ve Hacıfazlıoğlu'nun (2011) araştırma sonucuna göre de, öğretmenler yönetici olmak istememekte ve yöneticilik mesleğini kendileri için doyum sağlayıcı bir yükselme aracı olarak görmemektedir. Görüldüğü gibi, araştırma sonuçları ile paralel olarak, öğretmenlerin okul yönetimine ilgi duymamaları, okul yönetimine katılımı olumsuz etkileyen bir faktör olarak gösterilebilir. Ayrıca, okul yöneticiliğinin çalışma koşullarının cazip olmaması ile özlük hakları bakımından öğretmenlik mesleğinden çok farklı olmaması, daha fazla sorumluluk gerektirmesi, rehber öğretmenlerin okul yöneticiliği yapmak istememelerinin nedenleri arasında gösterilebilir. $\mathrm{Bu}$ sonuçlar, okul yöneticiliğinin tercih edilebilir bir meslek haline getirilmesi gerektiğini göstermektedir. Okul yöneticiliğinin meslekî ilkeler ile yasal koşullar bakımından yeniden düzenlenmesi, hizmet öncesi ve meslekî gelişime yönelik eğitimlerin gözden geçirilmesi faydalı olabilir.

Katılımcıların okul yöneticiliğini tercih durumuna ilişkin görüşlerine göre, rehber öğretmenlerin okul yönetimine katılımlarının yeterli olmadığı görülmektedir. Kaya'nın (1986) araştırma sonuçlarına göre, eğitim sisteminde karara katılma yeterli değildir. Değişik araştırma sonuçlarına göre, farklı eğitim kademlerinde görev yapan öğretmenler, okul yönetimine ve okullarda alınan kararlara etkili bir biçimde katılım sağlayamamaktadır. Örneğin, ilköğretim okullarındaki öğretmenler (Bilgin, 1996), okul öncesi öğretmenleri (Can ve Serençelik, 2017), ortaöğretim kurumlarında görevli öğretmenler (Can ve Bayramoğlu, 2016) ile ilkokullarda görevli sınıf öğretmenleri (Can ve Ozan, 2020; Demirtaş ve Alanoğlu, 2015), okul yönetimine ve okuldaki kararlara etkili olarak katılamamaktadır. Köklü’ye (2012) göre, ortaöğretim okullarında çalışan öğretmenler kararlara katılmaya çok istekli olmalarına rağmen, çok az katılabilmektedir. Görüldüğü gibi, farklı branşlarda görevli öğretmenler de okul yönetimine etkili katılım sağlayamamaktadır. Bu durum, öğretmenlerin okul yönetimine katılımları ile ilgili sorunların varlığını doğrulamakta ve ulusal düzeyde her kademede ve her branşta okul yönetimine etkili katılımı sağlayacak ve teşvik edecek uygulamalara ve politikalara ihtiyaç olduğunu göstermektedir. Araştırma sonuçlarından farklı olarak Göksoy’a (2014b) göre, okul yöneticileri öğretmenleri karara katmakta ve bu durum okulda verimliliği artırmaktadır.
Araştırmanın birinci alt probleminden elde edilen sonuçlara göre, rehber öğretmenler genel olarak, okul yönetimine katılımın sorunların çözümü bakımından gerekli ve önemli olduğunu düşünmektedir. Rehber öğretmenler, okul yönetimine katılımı, iş birliği, karara katılma, yönlendirme, bilgi alışverişi, destek olma ve başarı kavramları ile açıklamaktadırlar. Araştırma sonuçları ile benzer şekilde, Akdemir'e (2009) göre, öğretmenler okulda alınan kararlara daha fazla katılım sağlamak istemektedirler. Açıkgöz de (1984) öğretmenlerin okuldaki kararlara katılım isteklerinden daha az düzeyde katılım sağladıklarını belirtmektedir. Özdemir'in (1996) belirttiği gibi, örgüt içerisindeki farklı bireylerin farklı bakış açıları ve uzmanlıklarından faydalanılabilmesi için örgüt mensuplarının karar sürecine etkili katılımı sağlanmalıdır. $\mathrm{Bu}$ sonuçlar, rehber öğretmenlerin kendilerine uygun koşullar sağlanabilirse, okul yönetimine katılım sağlamak istediklerini doğrulamaktadır. Rehber öğretmenlerin okul yönetimine katılımı gerekli ve önemli görmesi, ancak okul yöneticiliği yapmak istemediklerini belirtmeleri, okul yönetimine katılımda öğretmenlerden kaynaklanmayan, eğitim sistemi ile ilgili çözüm bekleyen yapısal ve sistemsel sorunların varlığını ortaya koymaktadır. Eğitim politikaları bağlamında, bu yapısal ve sistemsel sorunların neler olduğunun ulusal düzeyde yapılacak kapsamlı alan araştırmaları ile ortaya koyulması ve çözüm önerileri geliştirilmesinin, rehber öğretmenlerin okul yönetimine katılımlarına olumlu katkılar sağlayacağı söylenebilir.

Araştırmanın ikinci alt probleminden elde edilen sonuçlara göre, rehber öğretmenlerin büyük bir çoğunluğu, toplantılar yoluyla okul yönetimine katılım sağladıklarını belirtmişlerdir. Araştırma sonucunu destekler nitelikte, Can ve Bayramoğlu'nun (2016) araştırma sonucuna göre, öğretmenler okuldaki yönetime genellikle resmî toplantılar yoluyla ve kısmî olarak katılabilmektedirler. Can, Gündüz ve Işsk-Can'ın (2013) araştırma sonucuna göre ise, resmî okul toplantıları öğretmenlerin okul yönetimine katılımını sağlamada yeterli değildir. Özdaş, Ekinci ve Öter'in (2018) araştırmasında öğretmen görüşlerine göre, öğretmenler kurulu toplantılarında, demokratik süreçler yeterince işlemediği gibi, kararlar ağırlıklı olarak müdürlerin yönlendirmesiyle alınmaktadır. Oysa, Göktürk ve Mueller'e (2010) göre, öğretmenlerin okul düzeyi ile ilgili alınan kararlara katılım sağlaması büyük önem taşımaktadır. Bu sonuçlar da öğretmenler kurulu toplantılarının okulda yönetime katılımda en önemli yöntemlerden biri olmasına rağmen, tek başına etkili ve yeterli olmadığını göstermektedir. Bu yüzden, okullarda rehber öğretmenlerin dahil oldukları her türlü toplantıların daha işlevsel olarak ve rehber öğretmenlerin katılımını sağlayacak şekilde düzenlenmesine ihtiyaç bulunmaktadır. Çünkü, okul toplantıları öğretmenlerin okul yönetimine katılımını sağlayan en önemli yöntemlerden biridir.

Rehberlik Hizmetleri Yönetmeliğine (MEB, 2017; MEB, 2020) göre, okul müdürünün başkanlığında rehber öğretmenler, öğrenci ve veli temsilcisi ile diğer öğretmenlerin katılımı ile oluşan rehberlik hizmetleri yürütme komisyonu birinci dönem başında, ikinci dönem başında ve ders yılı sonunda olmak üzere, en az üç defa toplanmaktadır. Bu toplantılarda rehber öğretmenlerin öğrenciler, aileler, idareciler ve öğretmenler arasında etkili iletişim kurulabilmesi için yapılacak çalışmaları belirlemesi, öğrencilerin sosyal, duygusal, akademik ve kariyer 
gelişimleri ile ilgili yapılacak çalışmalar başta olmak üzere, pek çok konuda görüş bildirmesi, kararların imza altına alınması, alınan kararlara katılım bakımından önemli görülmektedir. $\mathrm{Bu}$ komisyon toplantılarının, rehber öğretmenlerin yönetsel süreçlere katılımı ile fikir belirtmeleri, kararlara katılım sağlamaları bakımından önemli bir fonksiyonu yerine getirdiği söylenebilir. Ancak, rehber öğretmenlerin okul yönetimine katılımı bakımından komisyon toplantılarının ve alınan kararların kağıt üzerinde kalmaması, uygulanabilirliği ve etkililiği de büyük önem taşımaktadır. Çükü, Can’ın (2010) araştırma sonucuna göre, okullardaki rehberlik ile ilgili toplantı ve komisyonlar fonksiyonel olmadığı gibi, komisyon üyeleri rehberlik ve psikolojik danışmanlık alanı ile ilgili çalışmalara yeterli katkıyı sağlamamaktadır. Ayrıca, toplantı ve komisyon kararları etkili olarak uygulanmamaktadır. $\mathrm{Bu}$ sonucun da rehber öğretmenlerin okul yönetimine katılımını olumsuz etkilediği belirtilebilir.

Araştırmanın ikinci alt probleminden elde edilen sonuçlara göre, rehber öğretmenlerin resmî toplantılar haricinde ayrıca, görüş bildirme, eğitim semineri, bireysel görüşmeler, grup çalışmaları, resmî bilgi talepleri ve proje çalışmaları yoluyla okul yönetimine katılım sağlayabildikleri ortaya çıkmaktadır. Taiwo ve Ogunlade'ye (2020) göre, öğretmenler okuldaki finansal konular, problemlerin çözümü, disiplin sorunları, özlük hakları, akademik çalışmalar ile müfredata ilişkin kararlara katılım sağlamaları halinde, iş tatmininde olumlu gelişme olmaktadır. Tagay ve Sevi-Çakar'a (2017) göre, rehber öğretmenlerin okulda en çok iş birliği içinde oldukları kişiler sırasıyla okul müdürü, okul müdür yardımcısı ve öğretmenler olarak sıralanmıştır. $\mathrm{Bu}$ sonuç, rehber öğretmenlerin okullarda yöneticilerle görevleri gereği yakın çalışma içinde olduğunu ve doğal olarak yönetime kısmen de olsa bu şekilde katılabileceklerini göstermektedir. Rehber öğretmenlerin diğer branş öğretmenlerinden görevleri gereği bazı farklı özelliklere sahip olduğu, sürekli yöneticiler ve diğer öğretmenlerle iş birliği içinde olmalarının okul yönetimine katılımlarına olumlu katkı sağladığı belirtilebilir.

Araştırmanın üçüncü alt probleminden elde edilen sonuçlara göre, rehber öğretmenlerin genellikle danışmanlık alanında okul yönetimine katılım sağladıkları görülmektedir. $\mathrm{Bu}$ sonuç, rehber öğretmenlerin genel olarak kendi uzmanlık alanlarında, yönetimde alınan kararlara kısmen katılım sağladıklarını göstermektedir. Rehber öğretmenlerin okul yönetimine katılım sağladıkları diğer alanlar ise, öğrenci problemleri, özel eğitim öğrencileri ile yapılan çalışmalar ve bilgilendirme çalışmaları olarak belirtilmiştir. Bu sonuçlar da göstermektedir ki, rehber öğretmenlerin yönetime katılım alanları, çalışma ve görev alanları ile paralellik göstermektedir. Araştırma sonuçlarını destekler nitelikte, Millî Eğitim Bakanlığı Rehberlik ve Psikolojik Danışma Hizmetleri Yönetmeliği'ne (MEB, 2020) göre, rehber öğretmenlerin okullarda bireysel ve grupla psikolojik danışma kapsamında öğrencilere, öğretmenlere, yöneticilere ve velilere yönelik pek çok alanda rehberlik ve danışma faaliyeti yürütmesi gerekmektedir. $\mathrm{Bu}$ faaliyet alanları, araştırma sonucunda görüldüğü gibi, rehber öğretmenler tarafından aynı zamanda okul yönetimine katılımın en önemli ikinci yöntemi olarak görülmektedir. Okul yöneticilerinin rehber öğretmenlere, rehberlik ve psikolojik danışmanlık alanına uygun konularda daha fazla sorumluluk ve yetki vermesi, rehber öğretmenlerin yönetime ve kararlara katılımlarını olumlu etkileyebilir. Çünkü, Turnbull'a (2002) göre, öğretmen katılımının ne zaman ve hangi alanlarda en yararlı olduğu da önemlidir. Örneğin, sınıf yönetimi alanında yetki ve sorumluluk vermek, desteklemek farklı branşlar için olumlu katkı sağlarken, rehber öğretmenler için faydalı veya yeterli olmayabilir. Okul yönetimine katılımda, öğretmenlerin branşları, çalışma alanları, uzmanlıkları, yönetime ilgi duymaları, istekli olmaları, yönetici desteği ile çalışma koşulları da büyük önem taşımaktadır.

Araştırmanın dördüncü alt probleminden elde edilen sonuçlara göre, rehber öğretmenlerin okul yönetimine katılımlarının olumlu ve olumsuz etkileri bulunmaktadır. Rehber öğretmenlerin okul yönetimine katılımlarının en önemli olumlu etkisi olarak, demokratik bir okul kültürü oluşmasına katkısı olacağı belirtilmiştir. Ayrıca, araştırma sonuçlarına göre, öğretmenlerin okul yönetimine katılımının veli, öğretmen, öğrenci, yönetici ve çevreye destek olma, okulda sorunların çözümü, başarının artması, rehberlik hizmetlerinin daha etkin yürütülmesi, kalitenin sağlanması, veli, öğrenci ve çevrenin okula daha fazla güven duyması gibi olumlu etkileri olabileceği ifade edilmiştir. Araştırma sonuçları ile benzer şekilde, Özdemir'e (1996) göre, örgüt içerisinde karara katılma, değerleri paylaşma, bir gruba mensup olma duygusu, personelin moralini yükseltir. Böylece, personelin girişim kabiliyeti ve cesareti artar. Can ve Bayramoğlu'nun (2016) araştırma sonucuna göre, öğretmenlerin okul yönetimine katılım sağlaması, okulda demokratik bir okul kültürü oluşmasına katkı sağlamaktadır. Çünkü, Bäckman ve Trafford (2007), "demokratik", okul yönetiminin insan hakları değerlerine, okuldaki tüm önemli kararlarda öğrencilerin, personelin ve paydaşların katılımına ve yetkilendirilmesine dayandığını belirtmektedir. Karadağ ve Öner'in (2012) araştırma sonuçlarına göre ise öğretmenlerin okul yönetimine katılım düzeyleri ile örgüt iklimi algıları arasında anlamlı bir ilişki bulunmaktadır. Bu sonuçlar, öğretmenlerin okul yönetimine katılımlarının demokratik bir okul kültürü oluşması ile olumlu bir örgüt iklimi oluşmasına katkısı olacağını göstermektedir. Hallak'a (1995) göre, öğretmenler okulda yönetime katılım sağlayarak çalışma programını tasarlama ve karar alma sürecinde müdüre yardımcı olabilir. Ayrıca, öğretmenlerin okul yönetimine katılımı, öğretmenlerin okul müdürü ve diğer ögretmenler arasında bilgi alışverişi ile öğretim kalitesinin geliştirilmesine yardımcı olabilir. Çünkü, öğretmen katılımının olmadığı okullarda başarı, motivasyon ve okulun gelişimi de olumsuz etkilenmektedir. Güçlü'ye (2000) göre, öğretmenler okul iklimi, öğrenci devamsızlığı, disiplin politikaları, materyal seçimi, öğretme yöntem ve stratejileri, personel gelişimi ve hedef planlamasında kararlara katılım sağlamalıdır. Çünkü, Bursalıoğlu'na (2000) göre, öğretmenlere karara katılım olanağ1 verilmesi, eğitim-öğretim faaliyetlerini olumlu etkilemektedir. Değişik araştırmalarda (Aydın, 1994; Başaran, 1986; Başaran, 1996; Bursalığlu, 2000; Hoy, \& Miskel, 2012; Lunenburg, \& Ornstein, 2013; Özdemir ve Cemaloğlu, 2000; Rawis, \& Kaligis, 2017; Taiwo, \& Ogunlade, 2020), öğretmenlerin karara katılım oranı arttıkça, okul ve öğretmenler üzerinde olumlu etkileri bulunduğuna yönelik sonuçlara ulaşılmaktadır. Ayrıca, öğretmenlerin okullardaki karar alma süreçlerine etkili katılım sağlamaları demokratik yönetimin gelişimine (Özdemir ve Cemaloğlu, 2000), iş doyumunun artmasına (Demirtaş ve Alanoğlu, 2015; Taiwo, \& Ogunlade, 2020), iş birliği ve koordinasyona (Conley, 1991), müdürlerin kararlarının kalitesinin geliştirilmesine (Rawis, \& Kaligis, 
2017) olumlu katkı sağlamaktadır. Öğretmenlerin okulda alınan kararlara katılarak okul yönetimine yardım ve destekte bulunması sağlanmalı (Cemaloğlu, 2002), okul yöneticileri öğretmenlerin özellikle eğitimsel ve yönetimsel kararlara katılımını sağlamalı (Demirtaş ve Alanoğlu, 2015), politika yapıcıları ve okul yöneticileri, katılımlarının kalitesini artırmak ve görevlerini yerine getirirken morallerini yükseltmek için öğretmenleri okul yönetimine katmalıdır (Attri, 2014). Can ve Bayramoğlu'nun (2016) araştırma sonucuna göre, öğretmenler okul yönetimine katılım sağlayabilirse, okuldaki demokratik kültürün gelişmesi başta olmak üzere, yönetim, başarı, güvenlik, temizlik, veli ile ilişkiler, disiplin ve kuralların etkili uygulanması gibi konularda olumlu gelişmelere katkı sağlayacaktır. Aydın (1994), okul yöneticilerinin öğretmenleri yetenekli oldukları ve kendilerini ilgilendiren konularda yönetime katmaları durumunda, daha sağlıklı kararların alınabileceğini, özellikle kararların anlaşılması, benimsenmesi ve uygulanmasında olumlu etkileri olacağını belirtmektedir. Görüldüğü gibi, öğretmenlerin karara ve yönetime katılımlarının olumlu etkileri bulunmaktadır. Okul rehber öğretmenlerinin okuldaki görev, rol, sorumluluk ve uzmanlık alanları dikkate alındığında, okul yönetimine katılım sağlamalarının okulun bir bütün olarak eğitim-öğretim faaliyetlerinin niteliğinin artması bakımından yararlı olacağı belirtilebilir.

Araştırmanın dördüncü alt probleminden elde edilen sonuçlara göre, rehber öğretmenlerin okul yönetimine katılımlarının rol karmaşası, yanlış algılamalar, alan dışı talepler ve iş yükü artışına neden olabileceği şeklinde bazı olumsuz etkileri olabileceği belirtilmiş̧ir. Araştırma sonuçlarını destekler nitelikte, Hallak'a (1995) göre, öğretmenlerin okulda yönetime katılımının artması öğretim kalitesine zarar verebilir, çünkü akademik faaliyetlere ayrılan süre azalabilir. Akpınar ve Bengisoy’un (2017) araştırma sonuçlarına göre de okul müdürleri, rehber öğretmenlerden alan dişı istekler talep etmekte ve rehberlik ile ilgili plan, program ve çalışmalarda yeterli düzeyde iş birliği yapmamaktadır. Okul yöneticilerinin bu tutumunun rehber öğretmenlerin okul yönetimine etkili katılımlarını engelleyebileceği söylenebilir. Okul rehber öğretmenlerinin eğitim-öğretim faaliyetlerini aksatmayacak, rehberlik ve psikolojik danışmanlık faaliyetlerinin daha etkili yürütülmesini sağlayabilecek düzeyde ve uzmanlık alanları da esas alınarak, okul yönetimine katılımlarına olanak sağlanması faydalı olabilir.

Araştırmanın beşinci alt probleminden elde edilen sonuçlara göre, rehber öğretmenlerin okul yönetimine katılımlarını etkileyen en önemli değişken, okul yöneticilerinin olumsuz tutum ve davranışlarıdır. Ayrıca, rehber öğretmenler, ön yargılar, diğer öğretmenler, veliler, rehberlik hizmetleri ve çevre gibi faktörlerin de okul yönetimine katılımı olumsuz etkileyebileceği belirtilmiştir. Araştırma sonuçlarını destekler nitelikte, Can ve Ozan'ın (2020) araştırma sonuçlarına göre, yönetici ve öğretmenlerin olumsuz tutumları, öğretmenlerin okul yönetimine katılımlarını olumsuz etkilemektedir. Oysa, Sharma ve Kumari'ye (2017) göre, okul müdürleri planlama, organize etme, iletişim kurma, kontrol etme ve değerlendirme gibi yönetim faaliyetlerinde iyi sonuçlar elde etmek istiyorlarsa, öğretmenlerin bilgi ve deneyimlerinden faydalanmalı ve okul yönetimine katılımını sağlamalıdır. Aksay ve Ural'ın (2008) araştırma sonucuna göre, öğretmenler okullardaki yönetsel kararlara sınırlı düzeyde katılım sağlamaktadırlar. Araştırma sonuçları ile benzer şekilde Güçlü, Özer, Kurt ve Koşar'a (2015) göre, öğretmenler okullarda karar alma/karara katılma süreçlerinde en önemli faktörlerin okul müdürü, mevzuat ve müdür yardımcıları olduğunu düşünmektedir. Can ve Bayramoğlu (2016) ise öğretmenlerin okul yönetimine katılımını olumsuz etkileyen faktörler arasında, yöneticilerin olumsuz tutumları, öğretmenlerin ders yükünün fazla olması, öğretmenlerin yönetim konularına ilgi duymaması ve isteksiz davranışları ile okul yönetiminin baskıcı bir yönetim sergilemesi gibi faktörlerin etkili olduğunu belirtmektedir. Balyer, Özcan ve Yıldız'ın (2017) araştırma sonucuna göre, okul yöneticileri öğretmenlerin karara katılarak güçlendirilmesine uygun davranış sergilememektedirler. Can ve Serençelik'e (2017) göre, okul yönetiminin geleneksel yönetim anlayışına sahip olmas1, okul öncesi öğretmenlerinin okul yönetimine katılımlarını olumsuz etkilemektedir. Özden'e (1996) göre, katılmalı yönetimin başarısında büyük oranda okul yöneticisinin tavrı ve yaklaşımı büyük rol oynamaktadır. Çünkü, Adegoke'a (2010) göre, müdürlerin liderlik sitilleri, tutum ve davranışları, öğretmenlerin okuldaki karar alma sürecine katılımı üzerinde önemli derecede etkiye sahiptir. Erdoğan'a (2006) göre, yöneticiler hem göreve hem de ilişkiye önem vererek astlarının katılım düzeylerini artırmaları gerekmektedir. Araştırma sonuçlarını destekler nitelikte, Tagay ve Sevi-Çakar'a (2017) göre, rehber öğretmenler okulda görevlerini yerine getirirken okul yöneticileri, önyargılar, öğretmenler ve velilerden kaynaklanan sorunlar yaşamaktadır. Conley (1991) ise, öğretmenlerin okul yönetimine katılımın faydalı olacağına inanmalarına rağmen, zaman, öğretmen tutumları ve okulun yapısından kaynaklanan engellerle karşılaştıklarını belirtmektedir. Bu engeller, rehber öğretmenlerin de okul yönetimine etkili katılımını engelleyen faktörler olarak belirtilebilir. Şişman ve Turan'ın (2003) belirttiği gibi, Türk eğitim sisteminde kontrolü kaybetme kaygısından beslenen yönetim politikaları terk edilmeli, demokratik, katılımcı, şeffaf uygulama ve politikalar izlenmelidir.

Araştırmanın beşinci alt probleminden elde edilen sonuçlar ile paralel olarak, okul yöneticilerinin tutum ve davranışlarının öğretmenlerin yönetime katılımını etkilediğine ilişkin olarak, Altınkurt, Yılmaz, Erol ve Salalı'ya (2014) göre, okul yöneticilerinin yasal güç ve zorlayıcı güç kullanımı arttıkça, çalışanların kararların alınmasına katılımı ile ilgili olumsuz görüşü de artmaktadır. Ayrıca, öğretmenlerin çalıştığı kurumdan (duyuşsal, davranışsal) uzaklaşma, performansı düşüren etkenler ve okula karşı olumsuz tutumları artmaktadır. Okul yöneticilerinin ödül gücü kullanımı arttıkça öğretmenlerin kararların alınmasına katılımları artarken, öğretmenlerin çalıştığı kurumdan (duyuşsal, davranışsal) uzaklaşma, performansı düşüren etkenler ve okula karşı olumsuz tutumları ise azalmaktadır. Görüldüğü gibi, okul yöneticisinin tutum ve davranışları ile güç kullanımı şekli öğretmenlerin yönetime katılımlarını doğrudan etkilemektedir. Çünkü, Smylie'nin (1992) belirttiği gibi, öğretmenlerin farklı kararlara yönelik katılım istekliliklerinde müdür-öğretmen arasındaki çalışma ilişkilerinin büyük etkisi bulunmaktadır. Yıldırım'a (1989) göre, okul yöneticisi bireysel farklılıkları göz önüne alarak, istemeyenleri karara katılmaya zorlamamalıdır. Çünkü bazı öğretmenler, katılmalı yönetimi benimsemiyor olabilirler. Ayrıca, Üzüm ve Kurt'un (2019) belirttiği gibi, okulda katılımı esas alan bir yönetim yaklaşımı ve uygulamalarının yerleşmemiş olması da katılımı 
engelleyen faktörler olarak sıralanabilir. Meşeci, Özcan, Bozdemir ve diğerlerine (2007) göre, okul müdürleri, okul yönetimi ile okul psikolojik danışma ve rehberlik servisinin iş birliği yapması gerektiğini belirtmektedir. Ancak, okul müdürlerinin rehberlik hizmetleri üzerinde yeterli düzeyde etkisi olmadığı belirtilmektedir. Ayrıca, okul müdürlerinin rehberlik hizmetlerine yönelik temel beklentisinin sorunlu öğrencilerin tespit edilmesi ile öğretmen-öğrenci ve veli arasındaki ilişkinin geliştirilmesi olduğu belirtilmektedir.

Okul müdürlerinin rehberlik hizmetlerine bakışı, rehber öğretmenlerin okul yönetimine katılımlarında etkili olmaktadır. Can'ın (2010) araştırma sonuçlarına göre, rehber öğretmenler, okul yöneticilerinin rehberlik ile ilgili çalışmalara yeterli ilgiyi ve önemi göstermediğini, destek olmadıklarını ve rehberlik alanında yetersiz olduklarını, kendilerini bu alanda yetiştiremediklerini düşünmektedir. Hallak'a (1995), göre, öğretmenlerin pek çoğunun çalışma koşulları ile özlük haklarının yetersiz olmasının yönetime katılımlarını olumsuz etkileyebileceğini, bu yüzden öncelikle öğretmenlerin çalışma koşulları ile ekonomik haklarının geliştirilmesinin gerekli olduğunu belirtmektedir. Oysa, Başaran'a (1986) göre, yöneticiler çalışanların yönetime katılımı konusuna önem vermeli, yöneten ile yönetilenler arasındaki ilişkilerin gelişmesini sağlamalıdır. Ayrıca, yönetsel kararlarda objektifliği sağlayarak, kararların daha sağlıklı uygulanması ve uygulama sonuçlarından faydalanılmasına da olumlu katkı sağlayabilir. Meşeci, Özcan, Bozdemir ve diğerlerine (2007) göre, müdürler okul rehberlik servisi ve serviste çalışanları yetersiz bulmaktadır. $\mathrm{Bu}$ şekilde, okul yöneticilerinin rehber öğretmenlere yönelik olumsuz algılamalarının da rehber öğretmenlerin okul yönetimine etkili katılımını engelleyebileceği söylenebilir.

Araştırmanın beşinci alt probleminden elde edilen sonuçları destekler şekilde Can'a (2011) göre, öğretmenlerin rehberlik ve danışma alanında gelişim ihtiyacı bulunmaktadır. Ayrıca, öğretmenlerin, velilerin ve okul yöneticilerinin rehberlik konusunda eğitilmeleri gerektiği belirtilmektedir. $\mathrm{Bu}$ tespitlerin, rehber öğretmenlerin okul yönetimine etkili katılım engellerinden biri olduğu belirtilebilir. Balyer, Özcan ve Yıldız'a (2017) göre, öğretmenler, okul yönetim süreçleri konusunda bilgi sahibi olursa, karar süreçlerine katılımları, okulun etkililiğini ve verimliliğini artıracaktır. Bu yüzden, öğretmenlerin karar süreçlerine katılımı önemsenmeli ve desteklenmelidir. Ayrıca, öğretmenlerin kararlara katılımlarının sağlanması, öğretmenlerin meslekî statülerinin güçlendirilmesi ve meslekî özerkliklerinin sağlanması önerilmektedir. Chopra (2020), öğretmenlerin okulun karar alma süreçlerine ve uygulamalarına katılımının kolaylaştırılabilmesi için eleştirel düşünme, eleştirel pedagoji, dağıtılmış liderlik ve demokratik değerlere dayalı bir eşitlikçi eğitim sürecinin faydalı olabileceğini belirtmektedir.

Araştırmanın altıncı alt probleminden elde edilen sonuçlara göre, rehber öğretmenlerin okul yönetimine daha etkili bir şekilde katılım sağlayabilmeleri için, okul yöneticilerinin eğitilmesi, yasal düzenlemeler yapılması ve rehberlik hizmetlerinin düzenlenmesi öncelikle önerilmiştir. Ayrıca, rehber öğretmenlerin çalışma koşullarının iyileştirilmesi, rehber öğretmen ihtiyacının karşılanması, tüm çalışanların eğitilmesi, PDR toplantılarının aylık olarak düzenlenmesi ile okul-veli-çevre ilişkilerini geliştirmenin rehber öğretmenlerin okul yönetimine daha etkili katılımlarını sağlayabileceği belirtilmiştir. Araştırma sonuçları ile benzer şekilde, öğretmenlerin okul yönetimine etkili katılımını sağlayabilmek için yönetici ve öğretmenlerin eğitilmesi (Can ve Bayramoğlu, 2016) ile yasal ve pedagojik düzenlemelere ihtiyaç bulunduğu (Can ve Serençelik, 2017) belirtilmektedir. Özden'e (1996) göre, karar sürecine katılım veya sorun çözmeye katılım olarak adlandırılan "katılmalı yönetim" uygulama ağırlıklı olmalı, yani öğretmenler içinde yer aldıkları kararların uygulanmasını görmelidir. Bu şekildeki yönetimin öğretmenler için daha anlamlı olacağı ve örgütün sağlıklı işleyişine daha olumlu katkısı olacağı belirtilmektedir. Okul yöneticileri, rehberlik yürütme kurulu toplantıları başta olmak üzere, rehberlik ve psikolojik danışma alanına özgü uzmanlık gerektiren pek çok konuda rehber öğretmenlere bazı yetkilerini devredebilir. Böylece, rehber öğretmenlerin rehberlik hizmetlerinin planlanması, yürütülmesi ve değerlendirilmesi gibi aşamalarda okul yönetimine ve karar süreçlerine daha etkin katılımları sağlanmış olur. Balcı'nın (2001) belirttiği gibi, temel karar verme birimi olarak okullarda ögretmenlere daha fazla yetki ve sorumluluk verilerek, öğretmenlerin kararları sahiplenmeleri ve kararlara ortak olmaları sağlanabilir.

Araştırmanın altıncı alt probleminden elde edilen sonuçları destekler nitelikte, değişik araştırma sonuçlarına (Can, 2018; Can, Nikolayidis, \& Işı1k-Can, 2018) göre, 2017 tarihli rehberlik hizmetleri yönetmeliği ile rehber öğretmenlere alanları dışında bazı görev ve sorumluluklar yüklendiği, iş yüklerinin arttığı belirtilerek yönetmeliğin yeniden düzenlenmesi gerektiği belirtilmektedir. Millî Eğitim Bakanlığı 2023 Vizyon Belgesi'nde ise PDR hizmetlerinin mevzuat altyapısının yeniden yapılandırılacağının (MEB, 2018) belirtilmesi, rehber öğretmenlerin okul yönetimine daha etkili katılımlarını da esas alacak şekilde rehberlik alanında yeni yasal düzenlemelere ihtiyaç olduğunu doğrulamaktadır. Araştırmanın verilerinin toplanmasından sonra, Rehberlik ve Psikolojik Danışma Hizmetleri Yönetmeliği'nin (MEB, 2020) değiştirilmesi ve rehber öğretmenlerin görev ve sorumluluklarına ilişkin yeni düzenlemeler yapılması, araştırmada ortaya çıkan yasal düzenlemeler yapılması beklentisine yönelik sonuçları doğrulamakta ve desteklemektedir. Lalruatsanga'ya (2016) göre, eğitim liderleri, öğretmenlerin görev ve gelişim firsatları ile ilgili kararlara fiili katılımlarını artırmalı ve okul idaresi ile ilgili konularda daha fazla paylaşım sağlamalıdır. Ayrıca, öğretmenlerin yüksek standartta çalışmalarını sağlamak için tatmin edici hizmet koşulları ve sosyal yardım hizmetleri sağlanmalıdır. Öğretmenlerin okul yönetimine ve karar verme süreçlerine katılım sağlamaları için firsat verilmesi (Njoroge, \& Kathuri, 2017), yönetsel yardım ve destek grupları oluşturulması (Hallak, 1995), gerektiği vurgulanmaktadır. "Öğretmenler, sınıf içinde kendilerinden istenen müfredatı sadece uygulayan ve öğretim yapan, eğitim ile ilgili genel konulara dahil edilmeyen bir meslek elemanı görüntüsünden kurtarılarak eğitim sisteminin her aşamasında karar süreçlerine katılımları desteklenmelidir" (Balyer, Özcan ve Y1ld1z, 2017, s. 18). UNESCO'nun (2018) raporuna göre, öğretmenlerin karar süreçlerine katılımını engelleyen faktörler arasında, hizmet öncesi öğretmen eğitimi, aday öğretmen yetiştirme programları ile hizmet içi meslekî gelişim programlarının genellikle öğretmenlerin sınıf içi rollerini (ders planlama, sınıf yönetimi, öğretim ve öğrenci değerlendirmesi) gerçekleştirmeleri için gerekli bilgi ve becerileri geliştirmeye odaklanması yer almaktadır. Bu sonuç da göstermektedir ki rehber öğretmenlerin hizmet öncesi ve 
hizmet içi eğitimlerinde sadece öğretim etkinliklerine yönelik konular değil, aynı zamanda okul yönetim süreçleri ve okul yönetimine katılıma yönelik konulara da önem verilmelidir.

Araştırmanın birinci alt probleminden elde edilen sonuçlardan hareketle, rehber öğretmenlerin okul yönetimine katılımı, sorunların çözümü, iş birliği, karara katılma ve yönlendirme bakımından gerekli ve önemli görmelerine rağmen, okul yönetimine katılımın yüksek olmaması, konunun ulusal düzeyde kapsamlı olarak eğitim politikaları bağlamında araştırılmasının faydalı olacağını göstermektedir.

Araştırmanın ikinci alt probleminden elde edilen sonuçlardan hareketle, rehber öğretmenler okul yönetimine en önemli katılım yöntemi olarak toplantıları belirtmelerine rağmen, görüş bildirme ve karara katılmanın yeterli düzeyde olmaması, okul toplantılarının daha demokratik ve katılımeı bir yaklaşımla planlanması ve uygulanmasının faydalı olacağı belirtilebilir.

Araştırmanın üçüncü alt probleminden elde edilen sonuçlardan hareketle, rehber öğretmenlerin genel olarak kendi uzmanlık alanlarında kısmen de olsa yönetime katılım sağlayabildikleri dikkate alındığında, okul yöneticileri, okul rehberlik faaliyetleri ile ilgili olarak rehber öğretmenlerin çalışma konuları ve uzmanlıklarına uygun olarak yetki devri sağlayabilir, böylece kararlara doğrudan katılımlarını gerçekleştirebilir.

Araştırmanın dördüncü alt probleminden elde edilen sonuçlardan hareketle, okul yöneticileri okullarda daha demokratik bir okul kültürü oluşturabilmek, sorunların çözümünü kolaylaştırmak, okul başarısını artırmada ve kaliteyi sağlamada, rehberlik hizmetlerinin etkinliğini artırmada, rehber öğretmenlerin okul yönetimine ve okulda alınan kararlara daha fazla katılımlarını sağlayabilir.

Araştırmanın beşinci ve altıncı alt probleminden elde edilen sonuçlardan hareketle, rehber öğretmenlerin iş yükleri hafifletilmeli, görev ve sorumluluk alanları uzmanlıkları esas alınarak yeniden düzenlenmeli, okul yönetimine katılım kapasiteleri geliştirilmelidir. Böylece, rehber öğretmenlerin görev alanları ile ilgili olarak okul yönetimine daha etkili katılımları sağlanmış olacaktır. Ayrıca, rehber öğretmenlerin kendi görev alanları dışındaki rollerine yönelik karar verme yetkileri ve motivasyonları güçlendirilmeli, desteklenmelidir. Rehber öğretmenlerin okul yönetimine katılım engellerinin ortadan kaldırılmasında yönetici, veli ve öğretmenlerin eğitilmesi de önemli katkılar sağlayabilir. Araştırmanın beşinci alt probleminden elde edilen sonuçlardan hareketle, okul yöneticilerinin ve rehber öğretmenlerin okul yönetim süreçleri ve karara katılma konusunda bilgilendirilmeleri, hizmet öncesi ve hizmet içi eğitimde bu konulara ağırlık verilmesi faydalı olacaktır.

Araştırmanın altıncı alt probleminden elde edilen sonuçlardan hareketle, rehber öğretmenlerin okul yönetimine etkili katılımlarını sağlayabilmek için öncelikle okul yöneticilerinin eğitilmesi ve mevcut rehberlik hizmetleri yönetmeliğinin rehber öğretmenlerin okul yönetimine daha etkili katılımını sağlayacak şekilde düzenlenmesi gerektiği söylenebilir. Ayrıca, rehber öğretmen ihtiyacının karşılanması, rehberlik hizmetlerinin yeniden düzenlenerek çalışma koşullarının iyileştirilmesi, öğretmen, personel, öğrenci ve velilerin rehberlik hizmetleri ve okul yönetimine katılım konusunda bilinçlendirilmeleri faydalı olabilir.
Araştırmanın genel sonuçlarına göre, rehber öğretmenlerin okul yönetimine katılımındaki en önemli engelin okul yöneticileri olduğunun belirtilmesi, okul yöneticilerinin seçilmesi, yetiştirilmesi ve atanmasının yasal ve pedagojik olarak yeniden ele alınması gerektiğini ortaya koymaktadır. Okul yöneticilerinin seçilmesi ve atanması sürecinin liyakat temelinde ve mutlaka meslekî yeterlikleri sağlandıktan sonra gerçekleştirilmesinin faydalı olacağı belirtilebilir. Okul yöneticilerinin, ulusal düzeyde öncelikle okul rehberlik hizmetleri konusunda temel bir eğitimden geçirilmeleri ve bu konuda sürekli meslekî gelişimlerinin sağlanması, rehber öğretmenlerin okul yönetimine etkili katılımlarını sağlayabilir. Gelecekte yapılacak araştırmalarda, ulusal düzeyde rehber öğretmenlerin okul yönetimine katılım durumları, katılım engelleri, etkili katılımları için neler yapılması gerektiği nicel araştırma yöntemleri ile belirlenebilir. Ayrıca, rehber öğretmenlerin okul yönetimine ve okulda alınan kararlara katılım durumları, okul yöneticileri, diğer öğretmenler ve veli görüşlerine göre hem nicel hem de nitel araştırma yöntemlerine göre incelenerek, karşılaştırmalar yapılabilir.

\section{Kaynakça}

Adegoke, B. (2010). Influence of teachers' participation in decision making on job productivity in secondary schools.

Munich. https://www.grin.com/document/178868, web adresinden 22 Eylül 2020 tarihinde edinilmiştir.

Açıkgöz, K. (1984). Öğretmenlerin okuldaki kararlara katılımı. Yayımlanmamış Doktora Tezi. Hacettepe Üniversitesi Sosyal Bilimler Enstitüsü, Ankara.

Akdemir, A. S. (2009). Resmî ilköğretim kurumlarında görev yapan ögretmenlerin karara katılma durumu. Yayımlanmamış Yüksek Lisans Tezi. Beykent Üniversitesi Sosyal Bilimler Enstitüsü, İstanbul.

Akpınar, B. ve Bengisoy, A. (2017). Rehber öğretmenlerin okul müdürlerinin rehberlik hizmetlerine ilişkin görüşleri. Curr Res Educ, 3(3), 129-141.

Aksay, O. ve Ural, A. (2008). Ortaöğretim öğretmenlerinin okulla ilgili kararlara katılımı. Türk Eğitim Bilimleri Dergisi, 6(3), 433-460.

Aldemir, G. (1996). Öğretmenlerin okul yönetimine katılma düzeyleri. Yüksek Lisans Tezi. Gazi Üniversitesi, Eğitim Bilimleri Enstitüsü, Ankara.

Alıç, M. (1996). İnsan ilişkileri yaklaşımının eğitim yönetimine etkisi. Eğitim Yönetimi, 2(2), 173-182.

Altınkurt, Y., Yılmaz, K., Erol, E. ve Salalı, E. T. (2014). Okul müdürlerinin kullandığı güç kaynakları ile öğretmenlerin örgütsel sinizm algıları arasındaki ilişki. Journal of Teacher Education and Educators, 3(1), 25-52.

Apple, M. W., \& Beane, J. A. (2011). Demokratik okullar. (M. Sarı, Çev.). Ankara: Dipnot Yayınları.

Attri, A.K. (2014). Teachers participation in school administration: A study on gender difference. Scholarly Research Journal for Interdisciplinary Studies, 2(13), 1600-1606. 
Aydın, M. (1994). Eğitim yönetimi. Ankara: Hatiboğlu Yayınevi.

Babaoğlan, E. ve Y1lmaz, F. (2012). İlköğretim okullarında karara katılma. Mersin Üniversitesi Eğitim Fakültesi Dergisi, 8(3), 1-12.

Bäckman, E., \& Trafford, B. (2007). Democratic governance of schools. Council of Europe Publishing, Strasbourg.

Balc1, A. (2001). Etkili okul ve okul geliştirme, kuram, uygulama ve araştırma. Ankara: Pegem A Yayıncılık.

Balyer, A., Özcan, K. ve Yıldız, A. (2017). Teacher empowerment: School administrators' roles. Eurasian Journal of Educational Research, 17(70), 1-18.

Başaran, İ. E. (1986). Öğretmenlerin yönetime katılması. Eğitim Bilimleri Fakültesi Dergisi, 19(1-2), 117-121.

Başaran, İ. E. (1996). Eğitim yönetimi. Ankara: Yargıcı Matbaas1.

Bilge, C. (2008). Illköğretim öğretmenlerinin karara katılma ve iş doyum düzeyleri arasındaki ilişki (Ankara Ili Altındağ İlçesi Örneği). Yüksek Lisans Tezi, Gazi Üniversitesi, Eğitim Bilimleri Enstitüsü, Ankara.

Bilgin, T. (1996). Zonguldak merkez ilköğretim okullarındaki ögretmenlerin okul yönetimince alınan kararlara katılabilme derecelerinin değerlendirilmesi. Yayınlanmamış Yüksek Lisans Tezi. Gazi Üniversitesi Sosyal Bilimler Enstitüsü, Ankara.

Bingül, M. ve Hacıfazlıŏlu, Ö. (2011). Sınıf öğretmenlerinin yönetici olma eğilimleri: İstanbul Esenyurt İlçesi örneği. Uluslararası İnsan Bilimleri Dergisi, 8(1), 861-881.

Bogdan, R. C., \& Biklen, S. K. (1998). Qualitative research for education: An introduction to theory and methods. (3rd ed.). Boston, MA: Allyn and Bacon.

Bursalığlu, Z. (2000). Okul yönetiminde yeni yapr ve davranış. Ankara: Pegem Yayınları.

Camadan, F. ve Sezgin, F. (2012). İlköğretim okulu müdürlerinin okul rehberlik hizmetlerine ilişkin görüşleri üzerine nitel bir araştırma. Türk Psikolojik Danışma ve Rehberlik Dergisi, 4(38), 199-211.

Can, E. (2018). Millî Eğitim Bakanlığı Rehberlik Hizmetleri Yönetmeliğinin değerlendirilmesi. International Social Sciences Studies Journal, 4(23), 4556-4560.

Can, E., Nikolayidis, U., \& Ișık-Can, C. (2018). Millî Eğitimde rehberlik hizmetleri: Mevzuat değișikliği ve uygulamaya etkisi. E. B. Çelik, E. Kıral ve A. Çilek, (Ed.). Eğitimden kareler, içinde (ss. 171-201). Ankara: Eyuder yayınlar1.

Can, E. (2010). İlköğretim okullarında görevli rehber ögretmenlerin karşılaştıkları sorunların incelenmesi. 9. Ulusal Sınıf Öğretmenliği Eğitimi Sempozyumu, (20-22 Mayıs 2010), Elazı̆̆ ss. 911-917.

Can, E. (2011). Sinıf ögretmenlerinin rehberlik ve danışma ihtiyaçlarının belirlenmesi. 10. Ulusal Sinıf Öğretmenliği Eğitimi Sempozyumu, (5-7 Mayıs 2011) Sivas, 2(1), ss. 496-501.
Can, E., Gündüz, Y. ve Işık-Can, C. (2013). The role of committee meetings in teachers' participation in management. 2. International Conference on Interdisciplinary in Education, 30 Ocak-1 Şubat, Girne-KKTC.

Can, E. ve Serençelik, G. (2017). Okul öncesi eğitim öğretmenlerinin okul yönetimine katılımlarının incelenmesi. Dicle Üniversitesi Ziya Gökalp Ĕ̈itim Fakültesi Dergisi, 30, 525-542.

Can, E. ve Ozan, C. (2020). Sınıf öğretmenlerinin okul yönetimine katılımlarının incelenmesi. Millı̂ Ĕgitim Dergisi, 49(225), 55-87.

Can, E. ve Bayramoğlu, A. (2016). Ortaöğretimde okul yönetimine katılım. K. Beycioğlu, N. Özer, D. Koşar ve İ. Şahin, (Ed.). Eğitim yönetimi araştırmaları, içinde (s.104-125), Ankara: Pegem Akademi.

Celep, C. (1990). Öğretmenlerin okul yönetiminde karara katılması. Eğitim ve Bilim Dergisi, 14(78), 34-42.

Cemaloğlu, N. (2002). Öğretmen performansının artırılmasında okul yöneticisinin rolü. Millî Ĕgitim Dergisi, Klş-Bahar 2002, 153-154.

Chopra, P. (2020). Teachers' participation in school decisionmaking processes and practices: The case of an indian government secondary school. Italian Journal of Sociology of Education, 12(1), 41-55.

Conley, S. (1991). Review of research on teacher participation in school decision making. Review of Research in Education, 17, 225-266.

Creswell, J. W. (2002). Educational research: Planning, conducting and evaluating quantitative and qualitative research. Upper Saddle River, New Jersey: Merrill Prentice Hall.

Demirtaş, Z. ve Alanoğlu, M. (2015). Öğretmenlerin karara katılımı ve iş doyumu arasındaki ilişki. Ahi Evran Üniversitesi Kırşehir Eğitim Fakültesi Dergisi (KEFAD), 16(2), 83-100.

Ekiz, D. (2013). Bilimsel araştırma yöntemleri. Ankara: Anı Yayınc1lik.

Elma, C. (2000). Yönetsel etkililiğin bir göstergesi olarak yetki devri. C. Elma ve K. Demir. (Ed.). Yönetimde çağdaş yaklaşımlar, uygulamalar ve sorunlar, içinde (ss. 181-199), Ankara: Anı Yayıncılık.

Erdoğan, İ. (2006). Okul yöneticilerinin genel özellikleri ve yöneticilik tutumlarıyla ilgili bir araştırma. Hasan Ali Yücel Eğitim Fakültesi Dergisi, 1, 103-118.

Erkan, S. (2001). Okul psikolojik danışma ve rehberlik programlarının hazırlanması. Nobel Yayın Dağıtım, Ankara.

Glesne, C. (2013). Nitel araştırmaya giriş. A. Ersoy ve P. Yalçınoğlu (Çev. Ed.). Ankara: Anı Yayıncılık.

Gliner, J. A., Morgan, G. A., \& Leech, N. L. (2015). Research methods in applied settings an integrated approach to design and analysis. S. Turan (Çev. Ed.). Ankara: Nobel Akademik Yayıncılık. 
Goddard, Y. L., Goddard, R. D., \& Tschannen-Moran, M. (2007). A theoretical and empirical investigation of teacher collaboration for school improvement and student achievement in public elementary schools, The Teachers College Record, 109(4), 877-896.

Göksoy, S. (2014a). Participation of teachers in school administration and their organizational citizenship behaviors. International Journal of Humanities and Social Science, 4(7), 171-182.

Göksoy, S. (2014b). Okul yönetiminde karara katılım. Abant İzet baysal Üniversitesi Ĕgitim Fakültesi Dergisi, $14(2), 253-268$

Göktürk, S. ve Mueller, R. O. (2010). Multidimensionlity of teacher participation in school decision making. Journal of Applied Sciences, 10(14), 1421-1427.

Güçlü, N. (2000). Okula dayalı yönetim. Millî Eğitim Dergisi,

148 , http://dhgm.meb.gov.tr/yayimlar/dergiler/Milli_Egitim _Dergisi/148/6.htm, web adresinden 15 Eylül 2020 tarihinde edinilmiştir.

Güçlü, N., Özer, A., Kurt, T. ve Koşar, S. (2015). Okulda karar alımı döngüsü: Liderlik stilleri, karar verme stratejileri ve kişilik özelliklerinin karar sürecine etkilerinin incelenmesi. International Journal of Human Sciences, 12(2), 1756-1791. doi:10.14687/ijhs.v12i2.3470

Güçlüol, K. (1985). Eğitim yönetiminde karar ve örnek olaylar. Ankara: Kadığlu Matbaası.

Günay, G. ve Özbilen, F.M. (2018). Öğretmenlerin okul yöneticiliği istekliliğini etkileyen faktörlerin belirlenmesi. Turkish Studies Educational Sciences, 13(19), 1331-1344.

Gürkan, M. (2006). Meslekî ve teknik eğitim kurumlarında görev yapan öğretmenlerin karara katılma durumları. Yüksek Lisans Tezi, Yıldız Teknik Üniversitesi Sosyal Bilimler Enstitüsü, İstanbul.

Hallak, J. (1995). Managing schools for educational quality and equity: Finding the proper mix to make it work. Educational planning: The international dimension, pp. 107-118. Jacques Hallak, Francoise Caillods (Ed.) Garland Publishing, Inc. New York \& London.

Hoy, W. K., \& Miskel, C. G. (2012). Educational administration, theory, research and practice. S. Turan (Çev. Ed.). Ankara: Nobel Yayınları.

Karadağ, E. ve Öner, S. (2012). The relationship between the levels of participation of high school teachers in school management and their perception of organization climate. Journal of Research in International Business Management, 2(1), 10-15.

Karagöz, M.E. (2009). Anadolu liselerinde görev yapan ögrretmenlerin karara katılma durumları. Yüksek lisans Tezi, Yıldız Teknik Üniversitesi, Sosyal Bilimler Enstitüsü, İstanbul.

Karakütük, K. (2001). Demokratik laik eğitim, çağdaş toplum olmanın yolu. Ankara: Anı Yayınc1lık.
Karaman-Kepenekçi, Y. (2003). Demokratik okul. Eğitim Araştırmalarl, 4(13), 44-53.

Kartal, S. (2008). İlk ve ortaöğretim kurumlarında velinin okul yönetimine katılımı. Ahi Evran Üniversitesi Kırşehir Eğitim Fakültesi Dergisi (KEFAD), 9(1), 2330.

Kaya, Y. K. (1986). Eğitim Yönetimi. Ankara: Bilim Yayınları.

Köklü, M. (2012). Ortaöğretim okulları öğretmenlerinin kararlara katılma durumları, katılma istekleri, iş doyumları, çatışmaları yönetme biçemleri. Ĕğitim ve Bilim, $37(165)$. http://egitimvebilim.ted.org.tr/index.php/EB/article/vi ew/1223/423 adresinden erişildi.

Kuzgun, Y. (2009). Rehberlik ve psikolojik danışma. Ankara: Nobel Yayın Dağıtım.

Lalruatsanga, I. (2016). Participation of secondary school teachers in school management with reference to their gender, teaching experience and types of management in Aizawl city. Dissertation Master of Philosophy in Education of Mizoram University, Aizawl.

Lunenburg, F. C., \& Ornstein, A. C. (2013). Educational administration. G. Arastaman (Çev. Ed.). Ankara: Nobel Yayınları.

Meşeci, F., Özcan, N., Bozdemir, P. ve diğerleri. (2007). Öğretmen ve müdürlerin okul psikolojik danışma ve rehberlik servisine yönelik algıları. Hasan Ali Yücel Eğitim Fakültesi Dergisi, 7(1), 157-171.

Miles, M. B., \& Huberman, M. A. (1994). An expanded sourcebook qualitative data analysis. London, UK: Sage.

Millî Eğitim Bakanlığı (MEB). (2017). Millî Eğitim Bakanlığ Rehberlik Hizmetleri Yönetmeliği.10 Kasım 2017 tarih ve 30236 sayll R.G.http://www.resmigazete.gov.tr/eskiler/2017/11/20 171110-2.htm, web adresinden 24 Nisan 2020 tarihinde edinilmiştir.

Millî Eğitim Bakanlığı (MEB). (2018). Güçlü yarınlar için 2023 eğitim vizyonu belgesi. http://2023vizyonu.meb.gov.tr/doc/2023_EGITIM_VI ZYONU.pdf, web adresinden 14 Mayıs 2020 tarihinde edinilmiştir.

Millî Eğitim Bakanlığı (MEB). (2020). Millî Ĕ̆itim Bakanlığ Rehberlik ve Psikolojik Danışma Hizmetleri Yönetmeliği.14 Ağustos 2020 tarih ve 31213 sayılı R.G.

https://www.resmigazete.gov.tr/eskiler/2020/08/20200 814-2.htm, web adresinden 19 Eylül 2020 tarihinde edinilmiştir.

Mondal, P. (2016). Participation of higher secondary school teachers in school administration. Global Journal of Human Social Science, 16(6), 1-26.

Mosoge, M. J., \& Van Der Westhuizen, P.C. (1998). Schoolbased management: Implications for the new roles of principals and teachers. Koers, 63(1\&2), 73-87. 
Njoroge, N., \& Kathuri, N. (2017). Influence of participatory management on school performance in public primary schools in Nakuru North Sub County, Kenya. International Journal of Recent Research in Social Sciences and Humanities, 4(3), 33-43.

Öner, S. (2007). Ortaöğretim kurumlarında görevli ögretmenlerin okul yönetimine katılma düzeyleri ile örgüt iklimi arasındaki ilişki. Yüksek Lisans Tezi, Yeditepe Üniversitesi Sosyal Bilimler Enstitüsü, İstanbul.

Özdaş, F., Ekinci, A. ve Öter, Ö. M. (2018). Eğitim ve öğretimin geliştirilmesinde öğretmenler kurulu kararlarının etkisi. Turkish Studies Educational Sciences, 13(11), 1041-1058.

Özdemir, M. (2019). Nitel veri analizi: Sosyal bilimlerde yöntembilim üzerine bir çalışma. Eskişehir Osmangazi Üniversitesi Sosyal Bilimler Dergisi, 11(1), 323-343.

Özdemir, S. (1996). Okula dayalı yönetim. Eğitim Yönetimi, 2(3), 421-426.

Özdemir, S. ve Cemaloğlu, N. (2000). Eğitimde örgütsel yenileşme ve karara katılma. Millî Eğitim Dergisi, 146(2), 54-63.

Özden, Y. (1996). Okullarda katılmalı yönetim. Eğitim Yönetimi, 2(3), 427-438.

Rawis, J. A. M., \& Kaligis, J. N. (2017). Teacher participation in decision-making in high school achievement (Case Study on SMU Negeri 1 Manado). International Journal of Humanities and Social Science Invention, 6(5), 29-35.

Sharma, P., \& Kumari, S. (2017). A study of participation of secondary school teachers in administration. International Journal of Advanced Education and Research, 2(4), 234-238.

Smylie, M. A. (1992). Teacher participation in school decision making: Assessing willingness to participate. Educational Evaluation and Policy Analysis, 14(1), 53-67.

Sönmez, V. ve Alacapınar, F.G. (2013). Örneklendirilmiş bilimsel araştırma yöntemleri. Ankara: Anı Yayıncılik.

Şahin, H. (2010). Kişisel rehberlik ve psikolojik danışma. A. Kaya (Ed.). Psikolojik danışma ve rehberlik (ss. 157196). Ankara: Anı Yayıncılık.
Şişman, M. (2006). Ĕgitimde demokrasi ve sosyal adalet: Türkiye eğitim sisteminin değişmeyen miti. Türk Eğitim Sisteminde Yeni Paradigma Arayışları Bildiriler Kitabı, 4-5 Kasım, Ankara. Eğitim Bir-Sen Yayınlar1, 291-305.

Şişman, M. ve Turan, S. (2003). Eğitimde yerelleşme ve demokratikleşme çabaları, teorik bir çözümleme. Kuram ve Uygulamada Eğitim Yönetimi, 9(34), 300315.

Tagay, Ö. ve Savi-Çakar, F. (2017). Okullarda yürütülen psikolojik danışma ve rehberlik hizmetlerine ilişkin okul psikolojik danışmanlarının görüşleri. Ahi Evran Üniversitesi Kırşehir Eğitim Fakültesi Dergisi, 18(3), 1168-1186.

Taiwo, A. E., \& Ogunlade, L. A. (2020). Teachers' decisional participation and job satisfaction in secondary schools in Ekiti State, Nigeria. International Journal of Educational Administration and Policy Studies, 12(1), $1-11$. https://academicjournals.org/journal/IJEAPS/articlefull-text-pdf/7F6881563020, web adresinden 17 Eylül 2020 tarihinde edinilmiştir.

Taymaz, H. (1989). Okul yönetimi. Ankara Üniversitesi Eğitim Bilimleri Fakültesi Yayınları.

Turnbull, B. (2002). Teacher participation and buy-in: Implications for school reform initiatives. Learning Environments Research, 5, 235-252,

UNESCO. (2018). Improving teacher support and participation in Local Education Groups. Final projet report. UNESCO, France.

Üzüm, H. ve Kurt, T. (2019). Okullarda katılımcı karar verme sürecinin incelenmesi. Eğitim ve Toplum Araştırmaları Dergisi/JRES, 6(1), 95-112.

Westheimer, J. (2008). Learning among colleagues: Teacher community and the shared enterprise of education. In Cochran-Smith, M., Feiman-Nemser, S. and McIntyre, $\mathrm{J}$ (eds.). Handbook of research on teacher education. Reston, VA: Association of Teacher Educators; Lanham, MD: Rowman.

Yıldırım, İ. (1989). Okul örgütlerinde karar verme ve karara katılma. Eğitim ve Bilim, 13(73), 18-24.

Yıldırım, A. ve Şimşek, H. (2006). Sosyal bilimlerde nitel araştırma yöntemleri. Ankara: Seçkin Yayıncılık. 
Ek-1: Etik Kurul Onay1

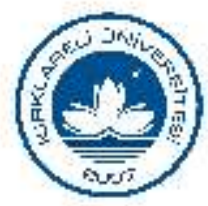

T.C.

KIRKLARELU் ÜNIVERSITESI REKTÖRLÜĞÜ

Bilimsel Araștrumalar ve Yaym Etiğ Kurulu

Say1 : 35523585-199-E.8726

$12 / 06 / 2020$

Konu : Etik Kurul Onayı

\section{Saym Doç. Dr. Ertuğ CAN}

Üniversitemiz Fen Edebiyat Fakūltesi Dekanlığ' nm 13/05/2020 tarih ve E.7920 sayll yazısı gereğg, Kuruhumuza göndermiş oldığumuz "Okul Yönetimine Katılım Rehber Öğetmenler Araştuma Önerisi ve Görüşme Sonulan" başhkh çahı̣̦ma incelemmiştir.

Yapılan incelemeden ve görüş̧melerden sonra; Kurulumuzca çalışmannn etik açıdan bir sakınca içermediğme oy birliğyle karar verimiş̧ir.

Bilgilerinizi ve gereğini rica ederim

Adres: Kurklareli Ǘniversitesi Rebtörlügüu Kayah Yerlesckesi

Telefon: 02882129670 Falks 02882129679

Merve KULAKLIOĞLU

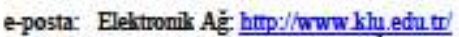

e-imzaludur

Prof Dr. Meryem ÇAMUR

Kurul Başkam Errak teyidi https://ebyssorgu lulu.edu.tr adresinden 0H66-UBK7-8PL I kodu ile yapulabilir. 